\title{
Host factors facilitating SARS-CoV-2 virus infection and replication in the lungs
}

\author{
Sébastien Boutin ${ }^{1,2}(1) \cdot$ Dagmar Hildebrand $^{1} \cdot$ Steeve Boulant ${ }^{3,4} \cdot$ Michael Kreuter $^{2,5} \cdot$ Jule Rüter $^{6}$. \\ Srinivas Reddy Pallerla ${ }^{6} \cdot$ Thirumalaisamy P. Velavan $^{6,7} \cdot$ Dennis Nurjadi $^{1}$
}

Received: 17 November 2020 / Revised: 1 June 2021 / Accepted: 18 June 2021 / Published online: 5 July 2021

(c) The Author(s) 2021

\begin{abstract}
SARS-CoV-2 is the virus causing the major pandemic facing the world today. Although, SARS-CoV-2 primarily causes lung infection, a variety of symptoms have proven a systemic impact on the body. SARS-CoV-2 has spread in the community quickly infecting humans from all age, ethnicities and gender. However, fatal outcomes have been linked to specific host factors and co-morbidities such as age, hypertension, immuno-deficiencies, chronic lung diseases or metabolic disorders. A major shift in the microbiome of patients suffering of the coronavirus disease 2019 (COVID-19) have also been observed and is linked to a worst outcome of the disease. As many co-morbidities are already known to be associated with a dysbiosis of the microbiome such as hypertension, diabetes and metabolic disorders. Host factors and microbiome changes are believed to be involved as a network in the acquisition of the infection and the development of the diseases. We will review in detail in this manuscript, the immune response toward SARS-CoV-2 infection as well as the host factors involved in the facilitation and worsening of the infection. We will also address the impact of COVID-19 on the host's microbiome and secondary infection which also worsen the disease.
\end{abstract}

Keywords SARS-CoV-2 $\cdot$ COVID-19 $\cdot$ Innate immune response $\cdot$ Co-morbidities $\cdot$ Host factor $\cdot$ Microbiome

Sébastien Boutin

sebastien.boutin@med.uni-heidelberg.de

1 Department of Infectious Diseases, Medical Microbiology and Hygiene, University Hospital Heidelberg, Im Neuenheimer Feld 324, 69120 Heidelberg, Germany

2 Translational Lung Research Center Heidelberg (TLRC), German Center for Lung Research (DZL), University of Heidelberg, Heidelberg, Germany

3 Division of Cellular Polarity and Viral Infection, German Cancer Research Center (DKFZ), Heidelberg, Germany

4 Department of Infectious Diseases, Virology, University Hospital Heidelberg, Heidelberg, Germany

5 Center for Interstitial and Rare Lung Diseases, Pneumology, Thoraxklinik, University of Heidelberg, Heidelberg, Germany

6 Institute of Tropical Medicine, Universitätsklinikum Tübingen, Tübingen, Germany

7 Vietnamese-German Center for Medical Research, Hanoi, Vietnam

\section{Introduction}

In December 2019, a new coronavirus named as the severe acute respiratory syndrome coronavirus-2 (SARS-CoV-2 or 2019-nCoV) was found responsible for acute atypical respiratory disease. This virus shared a strong homology with SARS-CoV, which was responsible for acute respiratory distress syndrome (ARDS) and high mortality in 2002-2003 [1]. SARS-CoV-2 (Severe Acute Respiratory Syndrome Corona Virus 2) is the etiological agent of Coronavirus disease 2019 (COVID-19) [2-4]. The first cases were reported at the end of 2019 in Wuhan, China. The virus quickly spread globally, and as of early fall 2020, more than 30,000,000 people have been infected by SARS-CoV-2 worldwide. SARS-CoV-2 is infecting primarily the respiratory system and caused the following symptoms: fever, dry cough and dyspnea [5] as well as lung abnormalities such as reduced lung function and pulmonary fibrosis [6]. Additionally, other organs can be affected, causing headache, dizziness, generalized weakness, digestive symptoms, vomiting and diarrhea [7, 8]. This broad range of symptoms is also heterogenous in the 
infected population with asymptomatic individuals and patients reaching significant hypoxia and in some cases ARDS. Severe disease progression often leads to a fatal outcome, with an increased incidence of mortality in the older population [9-11].

The management of the disease is limited to symptomatic treatment to decrease the severity of the symptoms as no curative therapy is available. To limit the spread of the virus, many countries decide to implement social distancing and lockdown. Many drugs such as antiviral agents, treatment to treat super-infection such as empirical antibiotics and antifungal drugs, have been tested in clinical trials without reaching a consensus on a definite therapy [12-14]. The course for a vaccine has also been initiated and became a worldwide priority leading to several candidate vaccines are now in clinical phase 3 [15-18].

However, the gain of knowledge of the host factor influencing SARS-CoV-2 virus infection and replication in the lungs is crucial for the development of an appropriate therapeutic approach. We will review the clinical aspects and basic features of SARS-CoV-2 and its impact of immune response and discuss the influence of co-morbidities, coinfection and microbiome changes on the course of the disease (Fig. 1).

\section{Etiology of SARS-CoV-2}

The precise origin of SARS-CoV-2 is still under debate; however, it is now broadly accepted that this virus, like its predecessors SARS-CoV and MERS-CoV (Middle East respiratory syndrome), has a zoonotic origin. It is still unclear whether SARS-CoV-2 has jumped directly from the bat to humans or whether there was an intermediate host where the bat coronavirus has evolved to jump into humans (pangolin, snakes, turtles and feral dogs) [19]. SARS-CoV-2 belongs to the family Coronaviridae genus betacoronavirus. Based on phylogeny, the virus was classified in a sister clade to the prototype human and bat severe acute respiratory syndrome coronaviruses (SARS-CoVs) of the species severe acute respiratory syndrome-related coronavirus [20].

SARS-CoV-2 like all Coronaviridae are single-stranded positive-sense enveloped RNA viruses which carry the largest genomes (26-32 kb) among all RNA virus families. Transcription of the SARS-CoV-2 genome is very complex and leads to the production of one full-length genomic and nine subgenomic RNAs all of which contain a 5'-cap structure and a 3' poly(A) tail. Additionally, it was reported that non-canonical subgenomic RNAs are also transcribed

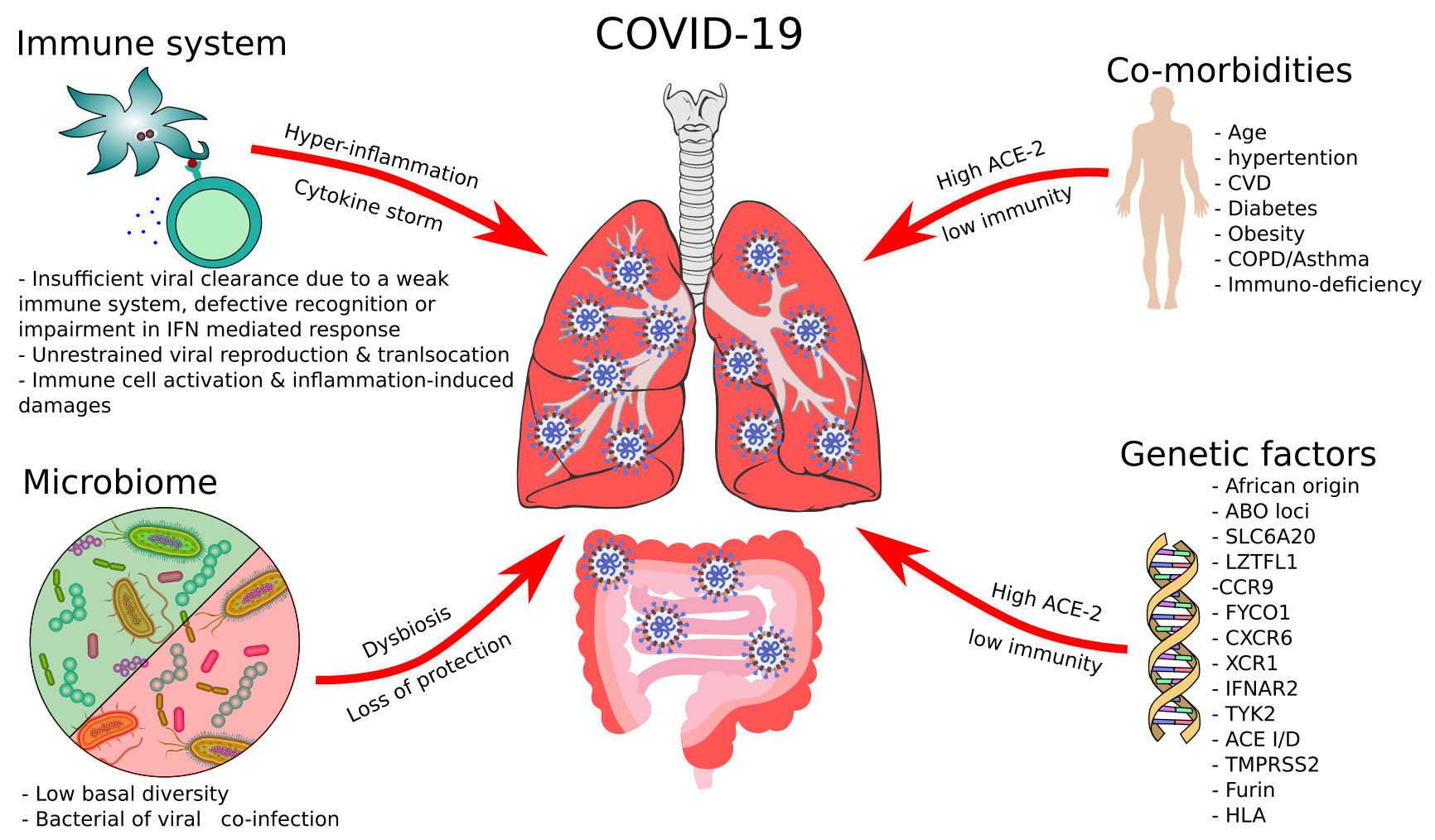

Fig. 1 Impact of immune system, co-morbidities, genetics and microbiome as host factors on the infection by SARS-CoV-2 and the progress of COVID-19 
through fusions, deletions, and/or frameshifts, but their functions remain elusive [21].

\section{Infection by SARS-CoV-2}

The life cycle of SARS-CoV-2 initiates with the spike proteins (S) located at the surface of the viral envelope binding the cellular receptor angiotensin-converting enzyme 2 (ACE2) [22]. Virus entry does not only rely on the cellular receptor ACE2 but also on the cellular serine proteases (TMPRSS2, TMPRSS11D and TMPRSS13), cysteine proteases, cathepsins B, L (CTSB/L) and furin that activate the spike protein through proteolytic cleavage [22-25]. Following entry and release into the cytosol, the full-length genomic mRNA is translated into 16 nonstructural proteins from two distinct open reading frames (ORFs). The viral genome is then used both as a template for the transcription of the different subgenomic RNAs and as a template for replication by the RNA-dependent RNA polymerase nsp12 [21]. Viral replication takes place in virus-induced replication organelles that are derived from intracellular membranes. These replication organelles are formed by endoplasmic reticulum-derived convoluted membranes that form double-membrane vesicles and open double-membrane spherules [26, 27]. Viral synthesis happens in the double-membrane vesicles [28] and, by analogy to SARS-CoV and MERS-CoV are believed to be induced by the viral protein nsp3 and nsp4 [27]. Upon infection, infected cells can detect the presence of viruses using pathogen recognition receptors (PRRs) which sense molecular signatures induced or directly associated with the pathogen or pathogen-associated molecular patterns (PAMPs).

\section{Immune response to SARS-CoV-2}

To date, how SARS-CoV-2 is sensed by infected cells and how the cells respond to viral infection is still under research. According to the composition of the RNA virus with different PAMPS and its replication cycle, sensing by extracellular as well as intracellular Toll-like receptors (TLRs) such as TLR3, TLR4 and TLR7/8 and retinoic acid-inducible gene-I-like receptors (RLRs) (RIG-I and MDA-5) seemed likely and has been shown meanwhile in different studies [29-31]. For example, it has been found that the spike protein of SARS-CoV-2 shows binding efficiency with the extracellular domains of TLRs including TLR1, TLR4 and, TLR6, with the strongest affinity with TLR4 [32]. Furthermore, studies on in-silico multi-epitope-based peptide vaccine candidates against the SARS-CoV-2 has proven effectively binding with TLR3, TLR4 and, TLR5 and activating of subsequent signaling pathways and inflammation [33]. Additionally, mRNA of
SARS-COV-2 NSP10, S2, and E proteins are considered as possible virus-associated molecular patterns that bind to TLR3, TLR9, and TLR7, respectively [34]. At this, it has been shown that targeting human TLRs with TLR agonists and thereby inhibiting SARS-CoV-mediated TLR activation and expression of pro-inflammatory cytokines might be therapeutically useful in COVID-19 [35].

Interestingly, a recent study suggests that the cGAS-STING pathway might also be involved in sensing SARS-CoV-2 infection [36] and this observation is supported by the fact that polymorphisms in the STING pathway might be associated with the pathogenesis of COVID19 [37]. Obviously, precondition of a protective antiviral immune response is the recognition of viral structures. Hence, genetically encoded defects regarding the viral recognition could worsen an infection. Indeed, Van der Made et al. could link loss-of-function mutations in the TLR 7 (sensor of viral RNA) [38] in myeloid cells, to a critical course of COVID-19 in otherwise healthy young men [39].

Recognition of PAMPs by PRRs induce a complex signaling cascade in the host cell. In consequence, a range of transcription factors are activated that drive the production of interferons (IFNs) and pro-inflammatory molecules [40, 41], indispensable for the full induction of the immune system. Especially, IFNs are considered as key antiviral cytokines in antiviral (including Coronaviruses) response as they induce the production of hundreds of interferon-stimulated genes (ISGs) known to exert broad antiviral functions [42-45]. In response to these cellular antiviral strategies, coronaviruses are developing a broad range of countermeasures to evade and interfere with the cell intrinsic innate immune response $[29,46]$. SARS-CoV-2 has been shown to be able to interfere directly with the production of IFN and with the IFN-mediated production of ISGs [47, 48]. On the host side, impairment of IFN-mediated antiviral response is mediated by type I interferon neutralizing antibodies [49]. Bastard et al. report that 101 of 987 patients with life-threatening COVID-19 pneumonia had neutralizing IgG auto-Abs against type I IFNs, at the onset of critical disease and absent in 663 individuals with asymptomatic or mild SARS-CoV-2 infection. The overwhelming majority of antibody-positive patients were male [49]. In line with these observations, another study from Hadjadj et al. describes a distinct phenotype in severe and critical patients, consisting of a highly impaired type I interferon response, associated with a sustained blood viral load and a pronounced inflammatory response (TNF- $\alpha$, IL-6) [50]. Accordingly, IFN neutralizing antibodies could inhibit elimination of the virus in the beginning of infection and thereby promote a severe and critical course. Importantly, neutralizing IgG auto-Abs against type I IFNs exist in almost all patients with autoimmune polyendocrinopathy syndrome type I (APS-1) [51] and are also found in women with systemic lupus erythematosus [52]. 
Virus-recognition and subsequent mediated inflammation and triggered adaptive immunity is crucial to fight and eliminate the pathogen. If the protective immune response is insufficient in the beginning, the virus can replicate with the consequence of virus-mediated impairments and hostmediated potentially life-threatening organ-restricted or systemic inflammation, culminating in a cytokine storm [53]. A cytokine storm can mediate various effects on the organism. Blood vessels are dilated, and blood pressure decreases, the epithelial barrier function is impaired, and the coagulase system is highly activated. As consequence, plasma leaks into the tissue, thrombi arise in the small vessels, and the oxygen supply of organ and tissue is insufficient. Organ failure and death are the most critical implications of a cytokine storm also observed in severe cases of SARS-CoV-2 infection [54]. The hyperinflammation in COVID-19 includes a variety of factors such as IFNs, chemokines, Colony-stimulating factors, TNF- $\alpha$ and interleukins (ILs), such as IL-6.

As ultimate result of the cytokine storm in SARS-CoV-2 infection, the ARDS might occur. ARDS is a hallmark of a critical course of COVID-19 and accounts for a significant number of deaths in patients [54]. ARDS is a form of severe hypoxemic respiratory failure characterized by inflammatory injury to the alveolar capillary barrier with extravasation of protein-rich edema fluid into the airspace. ARDS can be caused by bacterial sepsis as well as SARS-CoV and MERS$\mathrm{CoV}$ infections [55]. Kox and Kan with colleagues reported that cytokine levels in COVID-19 patients with developed ARDS are lower than in bacterial sepsis, the most common risk factor for ARDS [56]. However, the threshold are still sufficient to induce inflammation-mediated pathomechanism $[57,58]$. Evidence points towards a key role of thromboembolism and hypercoagulability that sustain pro-inflammatory cytokines-mediated effects leading to multiorgan failure [59].

Obviously, the immune response codetermines the outcome of SARS-CoV-2 infection. Predisposing host factors that might favor a severe COVID-19 course include those who inhibit the protective immune response on the first side and/or sustain a hyperinflammation at later stages of infection. On the cellular level, several immune cells are involved. Important players in the antiviral response are natural killer (NK) cells. NK cells are innate lymphocytes that circulate in the blood and infiltrate in parenchyma of peripheral tissue such as the lung upon infection [60]. The activation status of NK cells is regulated by the outcome of several activating and inactivating receptors-mediated signaling. Major histocompatibility complex (MHC) class I molecules are ligands for inhibitory or activating receptors [61]. Engagement of these receptors modulates NK cell responses and T-cell antigen receptor (TCR)-dependent T-cell activation. Expression of MHC class I is frequently impaired in virus-infected cells, which results in abolishment of NK cell inhibition and induction of the effector functions [61]. Full activation of NK cells requires type I IFNs or pro-inflammatory cytokines (such as IL-15, IL-12, IL-18) [62] released by infected and activated immune and nonimmune cells, such as airway epithelial cells [63, 64]. Once activated NK cells can, depending on the subtype, kill target cells and release inflammatory cytokines and chemokines, thus participating in the recruitment and activation of other leukocytes [65]. Given the importance of NK cell activity in early viral clearance and late immunopathology, a direct role for NK cells is suggested. However, the role of NK cells in COVID-19 severity has just begun to be analyzed. So far generated data report alterations in the NK cell numbers, function and phenotype that are associated with COVID19 severity. A study from Hadjadj et al. using peripheral blood from COVID-19 patients shows that NK cell numbers inversely correlated with disease severity. Here, infiltration of NK cells into the lung cannot be excluded. Furthermore, cells in patients with active disease highly expressed the inhibitory receptor NKG2 and displayed a hyporesponsive phenotype in respect of production of IFN- $\gamma$, TNF- $\alpha$, IL-2 and granzyme B [66]. Another study from Liao et al. could show that upon infection with SARS-CoV-2 NK cell infiltration of the lungs increases. Nevertheless, in severe disease, the proportions of NK cells were reduced with a high expression of inhibitory receptors [67]. A similar result was postulated by Carvelli and colleagues in peripheral blood. Absolute numbers of NK cells were significantly reduced in COVID-19 patients with developed pneumonia and ARDS compared to healthy controls and inhibitory receptors were more abundant on the cells [68]. Wilk et al. report from their study that CD56bright (cytokine producers) population was depleted in peripheral blood of all COVID-19 patients but the CD56dim (cytotoxic) population was depleted only in patients with severe COVID-19 [69]. Finally, Maucourant et al. claim that severe hyperinflammation is associated with the proliferation and activation of 'adaptive' NK cells, a subpopulation with enhanced antibody-dependent cellular cytotoxicity, as well as the arming of CD56bright NK cells with cytotoxic molecules. These results suggest that a distinct NK cell immunophenotype is associated with the severity of COVID-19 [70]. However, further studies need to be done to gain a clearer picture about the role of NK cells in disease morbidity.

Naturally, besides NK cells further cells of the innate arm of the immune system are modulated in SARS-CoV-2 infection and contribute to the clearance of infection as well as the course of disease. For the highly plastic monocyte population, it was shown that patients with mild COVID19 symptoms have high levels of inflammatory monocytes, which most likely contribute to an effective fight against the virus. In contrast, monocytes in more severe COVID-19 courses show an anti-inflammatory functional phenotype 
[71]. This points towards a reprogramming of monocytes during infection from an immunogenic to an immunosuppressive character that is also observed in bacterial infection and sepsis [72, 73] and could be critical in terms of complete clearance of SARS-CoV-2 and possible secondary infections. Not surprisingly, also the granulocyte population is altered in COVID-19. Neutrophils are the most common white blood cells and one of the first cells to migrate to the site of infection. Interestingly, abundance of immature neutrophil precursors is increased in patients with mild and severe courses. Additionally, Schulte-Schrepping et al. observed a correlation between disease severity and this emergency myelopoiesis [71]. In general, in SARS-CoV-2 infection, resting neutrophils seem to be replaced by various neutrophil clusters, including inflammatory, immunosuppressive as well as immature cells [74]. In more severe cases, mature neutrophils were shown to possess a rather immunosuppressive then immunogenic phenotype depicted by the expression of PD-L1 and impaired oxidative burst response [71]. This supports the finding that critical ill COVID-19 patients eventually fall into a state of immune silence after a period of excessive inflammation [74].

Importantly, lymphocytes of the adaptive arm of the immune system, seems to be important for COVID-19 outcome. In general, $\mathrm{T}$ cells are indispensable for coordination of antiviral immune responses. Activated by antigenpresenting cells, they regulate innate immunity, activate the humoral response, limit viral replication and remove infected cells [75]. Hence, $\mathrm{T}$ cells promote protective immunity against SARS-CoV-2 but also might sustain pathogenesis of COVID-19 when an exaggerated or misdirected T-cell response takes place. However, the impact of different subsets of $\mathrm{T}$ cells in protection or pathogenesis and severity is not solved yet. To put it simply, CD4+T cells help B cells to produce antibodies and macrophages to phagocytose and CD8+ T cells kill virus-infected cells [76]. Hence, both subtypes should limit viral replication. By consensus SARS-CoV-2 infected persons develop a strong and broad (not specific for spike2) CD4 T-cell as well as CD8 T-cell response including the development of memory lymphocytes, suggesting a long-term immunity [77]. Indeed, longterm T-cell-mediated immunity gained during infection with another coronavirus are accused to ensure a prompt and protective response and a mild COVID-19 course [78, 79]. Furthermore, lymphopenia of T cells (and B cells) is a hallmark of COVID-19, is more pronounced in severely ill patients [80, 81] and might affect especially CD8 T cells [82]. In mild courses, more $\mathrm{CD} 8+\mathrm{T}$ cells are found than in severe COVID-19 cases [83, 84]. In severe COVID-19 cases the $\mathrm{T}$-cell response is dominated by spike-specific CD4+ T cells, and as consequence of T-cell and B-cell collaboration high numbers of neutralizing high-affinity-antibodies are detected [85]. As many studies have shown a higher viral load in more severe COVID-19 cases, the increase in CD4+ T cells in those with a severe outcome, might be only a result of the increased antigenic burden. Nevertheless, CD4+ T-cell and/ or antibody responses could contribute to disease severity, rather than just reflecting it or contributing to a better viral clearance [85]. Further studies are needed to revise whether the early T-cell response is predictive of disease outcome.

\section{Comorbidities and risk factor in COVID-19}

SARS-CoV-2 is capable of infecting people of all ages, but older people or people with pre-existing medical conditions showed a predisposition to infection and severe forms of COVID-19 [86]. The sensibility of the elderly could actually be explained by the over-expression of ACE2 in the elderly or the high prevalence of co-morbidities in this cohort [87]. The list of co-morbidities includes obesity, diabetes, hypertension, lung, liver, and kidney disease; immune-compromised patients (cancer patients on chemotherapy, transplant recipients), smokers and patients taking steroids chronically [88]. The order of importance varied between studies but the major factors seems to be hypertension and cardiovascular problem followed by diabetes and respiratory underlying diseases [5, 88-94].

Mechanistically, the risk factor hypertension for a severe COVID-19 course, could be linked to the use of angiotensinconverting enzyme (ACE) inhibitors and angiotensin receptor blockers (ARBs) to treat patients with hypertension. The manipulation of the renin-angiotensin system (RAS) could have an implication on the invasion and replication of SARS-CoV-2 in the cells. Those treatments are known to potentially increase the levels of ACE2 in several tissues which could increase the power of invasion by SARS-CoV-2 [95-97]. Studies have shown different results regarding the impact of such inhibitors with deleterious effect as demonstrated in patients with underlying cardiovascular disease [98] or a beneficial effect on the clinical outcomes of COVID-19 patients with hypertension [99]. Altogether, the lack of knowledge does not allow us to draw a causal conclusion on the risk factor associated with hypertension nor decide to stop the use of ACE inhibitors and ARBs [100].

An underlying cardiovascular disease (CVD) is linked to a worst outcome in patient with COVID-19. Patients with CVD develop severe form of COVID-19 and face more likely fatal outcome $[101,102]$. The risk factors due to cardiovascular disease might depend on the same mechanistic as the hypertension because of the use of ACE inhibitors and ARBs. Furthermore, cardiac damage might occur during infection and treatment. Many antiviral drugs have an impact on cardiac insufficiency, arrhythmia or other cardiovascular disorders [103]. The virus itself, SARS-CoV-2 can induce myocardial injury, which is consistent with an increase in high-sensitivity cardiac troponin I (hs-cTnI) levels [5, 104]. 
Patients with COVID-19 often present heart palpitations and chest tightness and heart damage can occur even in the absence of underlying cardiovascular damage. The mechanism is still unclear, but the over-response of the cytokine storm syndrome might be the cause of the damage to the myocardial cells [105]. Furthermore, SARS-CoV-2 infection can also affect the heart of patients who have recovered from the infection, indicating a long-lasting impact on the cardiac system. Many patients showed post-COVID-19 myocardial dysfunction independently of the pre-existing cardiovascular disease [106, 107].

Metabolic disorders (MDs), such as diabetes and obesity are associated with a pro-inflammatory, and prothrombotic state that can promote atherosclerosis (accumulation of lipids and leucocytes in blood vessels, leading to the formation of plaque) that restricts blood flow and promotes organ dysfunction due to insufficient oxygen supply [108]. Hence, MDs are considered as major risk factor for a critical course of COVID-19 [109]. Diabetes, a common comorbidity in patients with COVID-19, is a multifaceted metabolic disorder affecting the glucose level in the organism. As a result of an absolute or relative insulin deficiency or resistance to its action, impaired glucose tolerance and hyperglycaemia takes place [110]. A small part of patients treated for diabetes also receive ACE inhibitors and ARBs, which could impact the prevalence of infection in this cohort [111]. In fact, diabetes is associated with a poorer outcome in COVID-19. This is most probably due to chronic inflammation with promoted atherosclerosis that sustains the symptoms in severe COVID-19 [112]. However, the underlying reasons for predisposing morbidity are complex. In addition to the general impairments in immunity (impaired neutrophil chemotaxis, phagocytosis, T-cell function) by which diabetes predisposes to infectious disease, diabetes might facilitate virus entry and replication. Roca-Ho et al. could show that diabetic mice have increased expression of ACE-2 in renal cortex, liver and pancreas. Although the upregulation of the receptor could not be confirmed in lungs this might predispose people with diabetes to infection with SARS-CoV-2 [113]. Furthermore, diabetes is associated with an increase in type-1 membrane-bound protease furin. Furin is involved in the entry of coronaviruses into the cell and therefore might facilitate viral entry and replication [114-116].

Obesity is defined by an excess accumulation of adipose tissue to an extent that impairs both physical and psychosocial health and well-being which can affect both children and adults [117]. Obesity is also linked to ACE2, adipose tissue express higher levels of ACE2 which might enhance the viral entry in adipocytes $[118,119]$. Therefore, a concern was raised if adipose tissue can serve as a reservoir for the spread of SARS-CoV-2 [120]. Furthermore, obesity does not come alone and is often associated with other comorbidities which are also increasing the risk of COVID-19 such as hypertension, diabetes, cardiovascular diseases and lung function decline. It is closely associated with the development and worsening of type 2 diabetes [121], implicating similar reasons for the reported worsening COVID-19 outcome like diabetes [122]. Briefly, the major reasons for promoting morbidity most probably include chronic inflammation and facilitated thrombosis. Dead and dying adipocytes, mediate infiltration and activation of macrophages, that release high levels of cytokines such as TNF- $\alpha$, IL-6, and IL-1 $\beta$ [123]. This increased inflammation might contribute to alveolar damage or systemic organic dysfunction in critical cases. Additionally, obesity-associated thrombosis [124] obviously displays the metabolic disease as a risk factor for severity in COVID-19 that can be viewed as prothrombotic disease and treated in some cases with heparin beneficially [125]. Furthermore, released hormones could be important. Obesity is associated with higher circulating leptin and lower circulating adiponectin. Adiponectin is considered as anti-inflammatory, and adiponectin-deficient mice develop inflammation of the pulmonary vasculature [126, 127]. This might account for facilitating a severe COVID19 course [128]. However, some risk groups tend to have lower and some tend to have higher adiponectin levels [129, 130] emphasizing the importance of the sum of factors for disease outcome. In summary, the factors displaying obesity as a risk factor in SARS-CoV-2 infection is complex and additional factors that might contribute are nicely reviewed by Lockhart and Stephen [122].

Within the high range of chronic respiratory distress, chronic obstructive pulmonary disease (COPD) and asthma were the most associated as comorbidity [5, 92]. COPD and asthma were already associated with other coronavirus infection, such as SARS-CoV and MERS-CoV [131]. However, in case of COVID-19, data are not clear if COPD really increases the rate of infection, but it is clear that patients with COPD are most likely to present severe symptoms [132, 133]. Most COPD patients have a long history of smoking or exposure to other harmful particles or gases, capable of impairing pulmonary defences even years after the absence of exposure [134, 135]. COPD is characterized by persistent respiratory symptoms and airflow limitation due to airway inflammation and/or alveolar abnormalities [136]. COPD patients showed an odds ratio of 2.681 for ICU admission, mechanical ventilation or death, even after adjustment for age and smoking [137]. They also are more prevalent in severe cases and dying cohort [9, 104, 137-139]. The mechanism favoring severe infection and worse outcomes for COPD patients is unclear but elevated ACE2 expression is associated with COPD and smoking [140, 141]. Leung and colleagues demonstrated in three separate COVID-19 cohorts with available gene expression profiles from bronchial epithelial cells that ACE-2 expression was significantly elevated in COPD patients compared to control subjects [140]. This might facilitate replication of the virus. 
Furthermore, impairment in the protective immune response in the beginning of infection is also probable as innate as well as adaptive immunity towards pathogens is impaired in COPD $[135,142]$. For example, the number of mature and thereby T-cell activating dendritic cells is rather low in COPD patients [143]. The numbers of alveolar macrophages are increased in COPD patients. However, their effector functions such as phagocytosis of pathogens, production of pro-inflammatory cytokines and antimicrobial factors, are downregulated [144]. Importantly, type I IFN production in lung epithelium and alveolar macrophages in response to viral infection is impaired in COPD [145]. Furthermore, COPD patients are less capable in producing mucosal virus-neutralizing sIgA [146]. Finally, also T-cell subsets are strongly affected in COPD. For example, CD8 T cells display impaired cytotoxic activity and an upregulation of inhibitory receptor programmed cell death protein-1 (PD-1). Importantly, COPD patients exhibit decreased numbers of pulmonary Treg cells, as well as reduced levels of FoxP3 mRNA and lung interleukin 10 secretion [147]. As regulatory $\mathrm{T}$ cells (Tregs) are essential to keep immune response and inflammatory reaction under control this in addition to increased ACE receptor and impairments in protective immunity, strongly suggests a predisposition of COPD patients for a critical COVID-19 course. Asthma is already known to lead to a higher sensitivity to develop viral infections due to a delayed innate antiviral immune response and impaired secretion of IFN- $\lambda$ [148]. However, there is a clear lack of evidence in the case of COVID-19 despite the claim that asthma is one of the comorbidity in some cohorts [92]. The rate of asthmatics infected seems low compare to the normal population rate in some other country and their odds ratio toward severity was not increased [149, 150]. This would go in line with a study comparing COPD and asthma, showing that asthmatic patients in contrast showed a lower risk of severe outcome compared to COPD [151]. The authors also showed that the ACE2 expression and protein level was significantly decreased in asthmatics compared to healthy controls and COPD patients. The most probable explanation in the heterogenous findings in literature is that asthma is often associated with other complications such as obesity $[152,153]$. With regards to other chronic lung diseases, interstitial lung diseases (ILD), data are sparser. Recently, it was shown that in patients with pre-existing ILDs hospitalization for COVID-19 is associated with a higher mortality, especially in those with idiopathic pulmonary fibrosis and those with a more advanced disease [94].

\section{COVID 19: relevance of host genetic factors}

While age and co-morbidities largely determine the clinical course of COVID-19, equally host genetic predisposition for life-threatening COVID-19 is being increasingly recognized in world populations. Identification of such host genetic factors associated with different clinical phenotypes help disentangle elements associated with susceptibility, hospitalization, virulence.

Clinical outcomes of COVID-19 have been shown to be associated with interindividual, as well as interpopulation, differences. While some African nations and South Asian countries with young populations report low incidence and mortality, genetic predisposition may limit viral infection and modulate COVID-19 immunopathogenesis [154]. For instance, irrespective of age, sex and co-morbidities, individuals with African descent in the UK and United States are associated with susceptibility [155], hospitalization [156, 157] and mortality [156]. Similar observations have been reported in non-Hispanic black, Hispanic, and non-Hispanic American Indian or Alaskan Native populations [158] and among few Asian population with hospitalization and mortality [155].

Both monogenic and polygenic risk variants can predispose to disease progression. In COVID-19, it is polygenic risk variants, as multiple loci are thought to influence the clinical phenotype [159]. Various genome wide association studies (GWAS) and candidate gene studies have investigated the association of inter- and intra-ethnic genetic variations with COVID-19 clinical phenotypes. Among the wellstudied loci of interest are blood group $\mathrm{ABO}$, genes that facilitate SARS-CoV-2 entry into epithelial cells, and genes that modulate innate and adaptive immune responses.

In particular, the SNP rs11385942 on chromosome 3, located at 3p21.31 and surrounding the genes SLC6A20, LZTFL1, CCR9, FYCO1, CXCR6, and XCR1, was identified as a risk variant in three independent GWASs [160-162]. Although there is supporting evidence showing a significant association of SLC6A20 [163, 164], CCR9 [164], CXCR6 [165], and FYCO1 [166] with COVID-19 susceptibility, it is yet unclear on the functional role of these studied variants. In another GWAS study from the UK, the rs13050728 variant of interferon-alpha/beta receptor subunit 2 (IFNAR2), which binds to type 1 interferons and is known to modulate signal transduction, is associated with critical clinical outcome, alongside the rs 11085727 variant in tyrosine kinase 2 (TYK2), which is implemental in cytokine signaling and interferon responses [161].

There is growing evidence from small observational studies to GWAS and country-level meta-regression analyses that the $\mathrm{ABO}$ blood group may play a role in the immunopathogenesis of SARS-CoV-2 infection, with group $\mathrm{O}$ individuals testing positive less frequently and group A having higher susceptibility to infection and a propensity for severe disease $[167,168]$. The rs657152 at locus 9q34.2, was identified from two GWAS studies [160,162]. Several hypotheses are postulated to explain the differences in SARS-CoV-2 infection by $\mathrm{ABO}$ type. The $\mathrm{ABO}$ blood group frequencies vary among human populations and the selective advantage of 
certain blood groups, perhaps related to exposure to specific pathogens, may have contributed to these variations. Also postulated are mechanisms that link blood type to individual risk for COVID-19: anti-A IgG antibodies in serum [169], lower ACE1 activity in blood type O [170], or the association of the $\mathrm{ABO}$ locus with different protein levels in plasma. These proteins include coagulation factors (factor VIII and von Willebrandt factor), IL- 6 and TNF- $\alpha$ as inflammatory markers, and CD209 (DC-SIGN) [171]. CD209 is an L-type lectin expressed on dendritic cells and macrophages and has been proposed as an alternative entry receptor for SARS-CoV-2 [172], making elevated CD209 levels a likely risk factor for increased viral entry and more severe disease phenotypes.

SARS-CoV-2 infects lung alveolar epithelial cells using the primary entry receptor angiotensin-converting enzyme II (ACE2) [173]. High ACE2 expression in patients with co-morbidities are associated with severe COVID-19 [174]. It is not apparent whether high ACE2 expression is a risk for severe disease, as other entry receptors are increasingly recognized. Elevated angiotensin II levels have been shown to have pro-inflammatory and prothrombotic properties, resulting in poor clinical outcomes [175]. Equally, studies highlight the importance of a genetic deletion/insertion of a $285 \mathrm{bp}$ Alu repeat sequence in intron 16 of the ACE gene fragment insertion (I allele) or the absence (D allele) [176]. ACE D allele was shown to increase expression of ACE2, and the D allele associated with COVID-19 severity [177] as well as frequency of hypoxia in SARS [178]. The ACE I/D allele distribution (rs4646994, ACE I/D polymorphism) from the Allele Frequency Database (ALFRED) (https:// alfred.med.yale.edu/alfred/index.asp) shows that ACE D frequency is high in African ethnic groups [176]. Coding variants within the ACE2 gene have been investigated in genetic association studies, in vitro and in silico, but no risk variants have been determined to date [179]. Despite the entry receptor ACE2, cleavage of the spike protein is facilitated by several host proteases, including TMPRSS2 and furins. Latini et al. identified missense variants in furin and TMPRSS 2 by whole-exome sequencing in hospitalized patients and observed significant differences in allele frequencies, particularly four variants that are common in patients (furin: rs769208985, rs114363287; and TMPRSS2: rs75603675, rs 12329760) [180].

Human leukocyte antigens (HLA) are essential for antigen presentation, T-cell activation and adaptive immune response. In silico studies show that HLA-A*02:02, HLAB*15:03, HLA-C*12:03 exhibit increased binding affinity for SARS-CoV-2 peptides and thus are likely to elicit an effective adaptive immune response [181]. However, to date, only one GWAS in a Chinese cohort found a significant association for HLA types (HLA-A*11:01, B*51:01, and $\left.C^{*} 14: 02\right)$ [182]. Furthermore, an Austrian study showed that the heterozygous HLA-E*0101/0103 variant and the HLA$E^{*} 0101$ allele was associated more severe COVID-19 [183].

The molecular basis of viral inhibition is triggered by the first line of defense. The PRRs of innate immune system, such as TLRs recognizes the PAMPs activating the Interferon regulatory factors (IRFs) and the interferon related immune responses. TLRs are well studied as key transducers of host type I IFN responses during viral infections. SARS$\mathrm{CoV}-2$ is unique compared to SARS-CoV as it has been shown to evade the host interferon responses and replicate effectively in lung alveolar cells [184]. A strong host type I IFN responses during early stages of an infection are crucial in determining the COVID-19 clinical course. However, an imbalanced immune response characterized by poor production of type I IFN and increased release of pro-inflammatory cytokines contributes to the severe forms of the disease [31]. Nonsynonymous variants in type I IFN pathway [185] and autoantibodies against IFN1s [49] have been associated with low or undetectable type I IFN levels during SARS-CoV-2 infection and in patients with viral pneumonia.

Several host-derived factors may be useful as therapeutic targets. Compared to the beginnings of the COVID-19 pandemic, acceleration, and prioritization of research on SARS-CoV-2 infection have brought novel and insightful knowledge, which may be useful in understanding the mechanism of entry and in-host replication of the SARS$\mathrm{CoV}-2$ virus. While the expression of certain proteins, such as TMPRSS2, TMPRSS4, high-mobility group protein B1 (HMGB1) and cathepsin L, is associated with enhanced viral entry and replication, other proteins and genes, such as dipeptidyl peptidase 4 (DPP4), 25-hydrocholesterol (25HC), lymphocyte antigen 6E (LY6E), interferon-induced transmembrane proteins (IFITM), zinc finger antiviral protein (ZAP), heat shock protein 90 (HSP90), and apolipoprotein B mRNA editing enzyme catalytic polypeptide (APOBEC) has been identified as protective in the pathophysiology of SARS-CoV-2 infection. An overview of the function of a selection of these host-derived proteins in the context of SARS-CoV-2 infection is summarized in Table 1.

\section{Interaction between the host microbiome and viral infection}

It is interesting to note that most of the comorbidity associated with COVID-19 such as hypertension, cardiovascular disease, diabetes or underlying respiratory disease is associated with a disturbance of the microbiome in gut or/and lung microbiome [186-191]. The microbiome is defined as the collection of genomes of all the microorganisms (bacteria, fungi, archaea and viruses) within a specific niche [192]. The human microbiome has such an impact in the health and functioning of our body that we are considered as a holobiont. The infection by SARS-CoV-2 begins in the lung 
Table 1 Selected host-derived proteins with potential therapeutical use for SARS-CoV-2 infection

\begin{tabular}{|c|c|c|c|}
\hline Protein & Name & Effect on COVID-19 disease progression & References \\
\hline DPP4 (syn CD26) & Dipeptidyl peptidase 4 & $\begin{array}{l}\text { Direct involvement in COVID-19 disease progres- } \\
\text { sion not yet clear, but inhibition of DPP4 modu- } \\
\text { late inflammation and exert anti-fibrotic activity. } \\
\text { High serum level may protect from infection } \\
\text { through inhibition of viral binding to CD26 }\end{array}$ & [321-324] \\
\hline $\mathrm{CH} 25 \mathrm{H}$ & Cholesterol 25-hydroxylase & $\begin{array}{l}\text { Induced in COVID-19 patients. CH25H converts } \\
\text { cholesterol to } 25 \text {-hydrocholesterol }(25 \mathrm{HC}) \text {. } 25 \mathrm{HC} \\
\text { inhibits SAS-CoV-2 infection in lung epithelial } \\
\text { cells and organoid models by blocking viral entry } \\
\text { through depletion of membrane cholesterol }\end{array}$ & [325-327] \\
\hline IFIH1 (syn. MDA5) & $\begin{array}{l}\text { Interferon-induced helicase } \mathrm{C} \text { domain-containing } \\
\text { protein } 1\end{array}$ & $\begin{array}{l}\text { Pattern recognition receptor, which can sense } \\
\text { corona virus RNA (also known as MDA5). Low } \\
\text { frequency allele SNP rs1990760 C > T is associ- } \\
\text { ated with lower IFN-b expression and increases } \\
\text { susceptibility to SARS-CoV-2 infection }\end{array}$ & {$[328,329]$} \\
\hline IFITM, IFITM2, IFITM3 & Interferon-induced transmembrane proteins $(1-3)$ & $\begin{array}{l}\text { Antiviral effector of antiviral activity of type I } \\
\text { interferons against SARS-CoV-2 replication. } \\
\text { Restriction of viral entry to low pH compart- } \\
\text { ments. Inhibition of S-protein fusion }\end{array}$ & {$[330,331]$} \\
\hline LY6E & Lymphocyte antigen $6 \mathrm{E}$ & $\begin{array}{l}\text { Restricts entry of corona viruses via interference of } \\
\text { the S-protein fusion }\end{array}$ & {$[332,333]$} \\
\hline ZAP & Zinc finger antiviral protein & $\begin{array}{l}\text { Expressed in human lung cells, endogenous ZAP } \\
\text { expression reduces SARS-CoV-2 replication in } \\
\text { human lung cells. Targets CpG dinucleotides of } \\
\text { SARS-CoV-2 }\end{array}$ & {$[334,335]$} \\
\hline HSP90 & Heat shock protein 90 & $\begin{array}{l}\text { Inhibition of HSP90 activity can reduce viral repli- } \\
\text { cation and pro-inflammatory cytokine expression } \\
\text { in airway epithelia }\end{array}$ & {$[336,337]$} \\
\hline APOBEC & $\begin{array}{l}\text { Apolipoprotein B mRNA editing enzyme catalytic } \\
\text { polypeptide }\end{array}$ & $\begin{array}{l}\text { APOBEC protein family, together with tetherin and } \\
\text { TRIM5a is part of the innate immunity against } \\
\text { viral infections. Host-dependent genome editing } \\
\text { of SARS-CoV-2 }\end{array}$ & [338-340] \\
\hline
\end{tabular}

and the major complications are lung infection and immune response dysregulation. Therefore, it has been hypothesized that the lung microbiome might be an important player in the initiation and progression of the disease [193]. In parallel, gut physiology seems to be affected during the disease as many patients suffer from diarrhea. This would also implicate a potential role of the gut microbiome, since the role of the gut microbiome in the gut physiology and the systemic immune response has been demonstrated [194, 195].

\section{Lung microbiome}

The lung has been for a long time considered a sterile organ, and every micro-organism found in the culture considered as pathogen [196]. However, nowadays, it is accepted that the lung is colonized by a diverse microbiome which contribute to build a proper immune homeostasis [197-201]. The constant exposure to microbes of the immune cells, primarily via $\gamma \delta \mathrm{T}$ cells, by microbes, will initiate the innate and adaptive immunity [202, 203]. The priming of immune cells by a rich airway microbiome avoid excessive immune response and a lower rate of allergic/asthmatic responses [189, 204, 205]. The protective role of the lung microbiome is due to the high diversity of organisms involved in both the immune priming and the competition within the microbiome. It has been documented in many studies that the occurrence of acute or chronic disease will modify the microbiome of the lung due to a disturbance of the balance colonization/elimination [206]. It has been demonstrated for many lung diseases such as ARDS, IPF, CF, COPD, bronchiectasis and asthma that the microbial structure of the lung is modified [207, 208]. Most of the time, the alpha diversity decreases with the establishment of a chronic infection leading to the dominance of single species. Most of the time, the dominant species belong to the phylum Proteobacteria that contains common lung-associated Gram-negative pathogens. Bacteroidetes and Firmicutes abundance decreases substantially during the establishment of the infection. However, it has not made clear yet if the alteration of the microbiome (dysbiosis) contributes to the disease progression or is a biomarker of the injury and inflammation. 
The impact of viral infection on the lung microbiota is poorly studied. However, the accumulated knowledge on the upper airways gives us input to hypothesize that changes in the microbiome might follow viral infections and influence the severity of the disease via secondary infections [209]. Most of the studies on the impact of viral infections upon the microbiome have been focused on the upper respiratory tract due to the easiness to acquire samples. The diversity of the microbiome seems to be impacted by a viral infection, but results are variable depending on the viruses and the studies. An increase in the diversity following a viral infection has been correlated with patients infected with influenza [210] or H7N9 avian influenza [211]. On the other hand, a decrease in the alpha diversity was observed in patient with influenza but only in symptomatic patients [212] and in another study comparing several viral infections (influenza, parainfluenza, rhino, respiratory syncytial, corona, adeno, or metapneumo viruses) [213]. Interestingly, this study showed that the oropharyngeal microbiome was more correlated to the age than the type of viruses infecting the patients. The structure of the microbiome of the upper airways is also impacted by viral infections and a clearer pattern seems to be drawn by studies. It has been shown that the phylum Firmicutes (Staphylococcus and Streptococcus spp.) and Proteobacteria (Haemophilus spp., Moraxella spp., Pseudomonas spp., Acinetobacter spp.) are increasing in abundances in patients with influenza [212, 214-216]. However, those specific phyla are known to be seasonally fluctuant and Proteobacteria are dominant in the nasopharyngeal microbiome during fall-winter [217]. Few studies have been focusing on the lower airways, but it seems that the same pattern with an increase of Proteobacteria in the microbiome of the lung at least in patients with chronic lung diseases [218] and in vitro model [219, 220].

In patients infected with SARS-CoV-2, only a few studies have been performed on the impact on the lung microbiome. It seems that as for other respiratory viruses such as influenza the microbiome of the lung is affected during the infection and a shift toward a dominating Proteobacteria is observed. Shen et al. compared 8 patients with COVID19 to 25 patients with community-acquired pneumonia (CAP), and 20 healthy controls [221]. They observed that the microbiome of the patient with COVID-19 was more closely related to the one of the CAP patients, the microbial composition in the bronchoalveolar lavage fluid (BALF) was dominated by either pathogenic bacterial strains or commensal bacteria commonly found in the upper respiratory tract. A second study with a slightly bigger cohort of 20 patients also showed that the microbiome of the lung shift to a mono-specific microbiota dominated by a Proteobacteria, which in this study was mostly Acinetobacter [222]. The analysis of the fungome also showed that Cryptococcus was the most dominant fungi which might be the results of an immune defect. A study based on a bigger cohort, comparing 62 COVID-19 patients to 125 non-COVID-19 pneumonia showed that COVID-19 patients had a reduced alpha diversity and the presence of potentially pathogenic microbes was detected in $47 \%$ of the cases [223]. Those studies do not imply causality or kinetic of infections, but it seems most likely that the viral infection by SARS-CoV-2 induces a dysbiosis of the lung which might, in turn, cause a secondary bacterial or fungal infection increasing the severity and fatality of the disease.

\section{Gut microbiome}

Although the respiratory organs is the main target for the clinical presentation of SARS-CoV-2 infection, gastro-intestinal symptoms have been reported on a subset of patients [224, 225]. Indeed ACE2, the receptor for SARS-CoV-2 spike protein is highly expressed in intestinal enterocytes [226, 227]. Moreover, viral RNA can sometimes be detected in rectal swabs after nasopharyngeal swabs have tested negative, suggesting the importance of the gut as a secondary niche for SARS-CoV-2 [228, 229]. In an in vitro intestinal organoid infection model, Lamers et al. demonstrated that enterocytes can be infected by SARS-CoV-2 and more importantly, the intestine may serve as an additional niche for SARS-CoV-2 to replicate within the human body and imply a secondary faecal-oral transmission route besides aerosols [230, 231].

Several symptoms of COVID-19 are directly implicating gut function such as digestive symptoms, vomiting and diarrhea [7, 8]. Gastro-intestinal symptoms are often link to severe COVID-19 complications [232]. The presence of digestive symptoms such as diarrhea, are known to be associated with a dysbiosis of the gut microbiome [233]. Furthermore, the role of the gut microbiome in the predisposition to and severity of viral infection is already recognized $[234,235]$. This role is mostly due to the impact of the gut microbiome on the systemic immune system. The healthy gut microbiome produces bacterial metabolites which help to maintain the intact epithelial integrity, regulatory T-cell development, and low inflammatory immune state [236]. The major class of metabolites are short-chain fatty acids (SCFAs) such as acetate, propionate, and butyrate which promote the development of regulatory $\mathrm{T}$ cells [237, 238], induce "tolerogenic" immune response [239] and limit autoimmunity [240, 241]. On the other hand, SCFAs also promote immune response to pathogens via the production of AMPs and defensins [242], IL-18 and LL-37 production [243, 244]. A dysbiosis of the gut microbiome and especially in the microbes involved in the production of such metabolites will favor infection.

Several studies have been performed to evaluate the impact of COVID-19 on the gut microbiome. The first study on 15 patients demonstrated a gut microbiome fingerprint 
characterized by a decrease of the beneficial commensals and increase of opportunistic pathogen [245]. This dysbiosis was associated with the severity of the disease. The abundance of Coprobacillus, Clostridium ramosum, and Clostridium hathewayi correlated positively with COVID19 severity while the abundance of Faecalibacterium prausnitzii showed the opposite effect. The dysbiosis was prolonged through the time of hospitalization despite the clearance of SARS-CoV-2 and resolution of the respiratory symptoms. Furthermore, the dysbiosis was also associated with higher levels of the virus in the feces. The species $\mathrm{Bac}$ teroides dorei, Bacteroides thetaiotaomicron, Bacteroides massiliensis, and Bacteroides ovatus correlates negatively with the SARS-CoV-2 load in fecal samples which would be explained by the fact that that those species downregulate the expression of ACE2 in the murine gut.

A study on 30 patients with COVID-19 also showed that the gut microbiome was associated with a dysbiosis compared to healthy controls. COVID-19 patients showed a significantly reduced bacterial diversity due to an overgrowth of opportunistic pathogens (Streptococcus, Rothia, Veillonella and Actinomyces) and a decrease of beneficial symbionts [246]. Another group worked on the transcriptional activity of SARS-CoV-2 in the feces of 15 patients with COVID-19 and showed that the gut microbiome was correlated to the viral transcriptional activity [247]. The fecal microbiome characterized by higher abundances of bacterial species Collinsella aerofaciens, Collinsella tanakaei, Streptococcus infantis, and Morganella morganii were typical of a high SARS-CoV-2 infectivity. On the other hand, fecal samples with low-to-no SARS-CoV-2 infectivity showed a higher abundance of Parabacteroides merdae, Bacteroides stercoris, Alistipes onderdonkii, and Lachnospiraceae bacterium, which are known producer of SCFA.

Finally, a study performed in 31 patients with COVID19 showed that a blood proteomic risk score based on 20 proteomic biomarkers was associated with the severity of COVID-19 [248]. The authors of this study also correlated the gut microbiome to the PRS and found that 20 most important OTUs belonging to the Bacteroides, Streptococcus and Lactobacillus genus, Ruminococcaceae and Lachnospiraceae family and Clostridiales order. Those 20 OTUs could predict the PRS with good power $\left(R^{2}=0.59\right)$ especially in comparison to classical demographic and lab parameter such as age, BMI, sex, blood pressure and blood lipids. Those results indicate that the change in the microbiome might precede the changes in the blood proteomic biomarkers. Furthermore, this study showed a negative correlation between the Bacteroides genus, Streptococcus genus and Clostridiales order with most of the pro-inflammatory cytokines, while Ruminococcus and Lactobacillus genus were positively correlated.
The gut homeostasis has also been linked to ACE2 which regulates via a renin-angiotensin system (RAS) independent function the amino acid homeostasis and expression of antimicrobial peptides. ACE2-KO mice showed a decreased expression of antimicrobial peptides and exhibited altered intestinal microbial composition [249]. Furthermore, other coronavirus cause a downregulation of ACE2 levels in tissues to improve the viral replication efficiency and pathogenicity and it has been hypothesized than SARS-CoV-2 might act the same way [250, 251]. The link between COVID-19 and gut dysbiosis can be explained by the ACE2 imbalance, which bring together the development of the virus in the gut and the viral load and the gut dysbiosis.

\section{Gut-lung axis}

As both lung and gut microbiome seems imbalanced during COVID-19, it highlights once more the systemic impact of the immune response and the link between the gut and the lung. This link called the "gut-lung axis" conceptualize that the gut microbiome composition influences the lung's immune response and by extension the lung microbiome and infection in the lung can also switch the gut microbiome composition toward pro-inflammatory status [252-254]. This concept introduces the impact of host-microbe as well as microbe-microbe interactions on localized and systemic immune response and the course of respiratory diseases. The gut is primordial to prime the mucosal immune response, and a perturbation of the normal gut microbiota may be associated with the development of an abnormal systemic mucosal response meaning the mucosal immunity is disturbed at distal mucosal sites, including the lung [255, 256]. This can be mediated by the migration of immune cells from the gut to the different organs through the lymphatic system [257]. Activated T and B cells can also move into the circulation and migrate from intestinal to the bronchial epithelium and lymphoid tissues [258]. While the immune system regulates the translocation of bacterial cells in the bloodstream, surviving bacteria, fragments of dead bacteria, bacterial metabolites such as SCFAs travel through the systemic circulation [256, 259]. Those factors will modulate distally the lung immune response [254, 260, 261]. The gut-lung axis and the microbiome of both niches are of high importance in many respiratory diseases and especially in ARDS, which is a common and severe complication of COVID-19 [262, 263]. Therefore, it seems that lung microbiome and gut microbiome are good biomarkers to predict the predisposition to COVID-19 and the severity of the outcomes. Furthermore, discussion and clinical trials on the use of microbiome transplantation and probiotics in COVID-19 patients to reduce the severity and infection are ongoing [264-266]. 


\section{Microbiome-viral interaction}

The lung and gut microbiome of healthy person present some specific composition such as a lung microbiota is dominated at the phylum level by Firmicutes, Bacteroidetes, Proteobacteria, Fusobacteria and Actinobacteria and at the genus level, Streptococcus and the anaerobic genus Prevotella and Veillonella originating from the upper airways are the most predominant [157-159]. In the gut, the homeostasis of the microbiota and low abundance of proteobacteria is crucial as it has been linked with less risk of obesity, cardiac disease and infection [267, 268]. The microbiome is highly personalized, and many lifestyle factors are influencing the microbiome. Those changes impacted mostly the diversity of the microbiome and therefore the protective role which relies on the competition between microorganisms and functional redundancy. By occupying the niche, the commensals microbes avoid the growth of potentially harmful pathogens [171]. Furthermore, a dysbiosis in the microbiome will triggers a change from commensal relationship to pathogenic relationship [269, 270]. In many cases, the decrease of diversity will increase the competition between the survivors and highly competitive opportunistic pathogens such as ESKAPE pathogens or Staphylococcus will become the dominant member of the microbiome.

A pathogen-dominated microbiome can also lead to an increase in co-infection. For several viral respiratory infections, the interaction between virus and commensal bacteria may result in a pathogenic synergism and complicate the course of diseases leading to increased morbidity and mortality [271, 272]. The mechanism behind the poor outcome of bacterial co-infection in underlying viral infection is complex, often pathogen-specific, and involves viral-bacterial interaction (direct) and their interaction with the host's immunity (indirect) [273, 274]. One of the best-studied examples of viral-bacterial synergism is the interaction between influenza A virus and the bacterial pathogens, $S$. aureus and $S$. pneumoniae [275]. Although both bacterial pathogens may be a harmless commensal, in certain circumstances, these bacteria may undergo a transition from harmless commensals to invasive infectious agents [276]. Viral infection may facilitate the transition from carriage to infection. It is postulated that an initial viral infection may cause cellular damage to the respiratory epithelia, such as cell tight junctions, thus leading to a release of pro-inflammatory and danger signals [277]. This damage may expose the basal membrane and other important attachment sites for bacterial adhesion, hence leading to increased adherence and expansion of opportunistic pathogens $[277,278]$. The adhesion of bacterial cells to cellular structures and epithelia is the first and essential step to enable entry and to initiate bacterial infection [274, 279]. In vitro and in vivo experimental data suggest that underlying influenza $\mathrm{A}$ infection can enhance $S$. aureus adhesion to the cell surface
[280, 281]. In a murine model, the clearance of S. aureus was impaired by a concomitant influenza infection, hence increasing their susceptibility to $S$. aureus infections [282]. Of course, the virus-induced cellular damage is not the only factor for cellular damage, which can promote bacterial adhesion and invasion. Many predisposing factors, pre-existing conditions and underlying diseases may equally influence the propensity to acquire bacterial-viral co-infection.

Direct viral-bacterial interaction has also been demonstrated in numerous in vitro and animal studies. For example, $S$. aureus colonization was shown to affect viral load and influenza virus clearance in animal models [283-285]. Whereas virus-virus interactions are mostly competitive in nature [286], bacteria-virus interactions have been described as synergistic. This implies that potential virulence may be enhanced due to the virus-bacteria interaction [286]. One explanation could be that the shift in the local microbiotaequilibrium, promote commensal bacterial-bacterial interaction in the battle for space and nutrients [287]. Another factor, which should be considered is the immune phenotype associated with the composition of the commensal bacterial population. As an example, certain host immune phenotype is associated with the colonization with S. aureus [288-291]. As a result of a viral infection, type I interferon (IFN) production may be induced and interferes with the Th1 and Th17 immune response, which is essential for efficient clearance of $S$. aureus $[292,293]$. Type I IFN inhibits the IL-23-dependent induction of Th17 immunity in the respiratory tract and consequently leading to lower levels of IL-17 producing CD4+ and $\gamma \delta$ T cells and ultimately less IL-17 and IL-22 production. Both cytokines are important for $S$. aureus carriage [289]; IL-17 is essential for the clearance of S. aureus [292], whereas IL-22 regulates the antimicrobialpeptide, such as defensins, production by the innate immune cells [293]. Consequently, it is possible that a viral infection can modify the local immune phenotype, which may drive a commensal population into a dominating pathogen through dysbiosis, thus causing secondary infections. Due to the lack of high-quality experimental data on the viral-bacterial interaction for SARS-CoV-2 and S. aureus or other commensals, it is not possible to postulate to which extent these factors apply to the occurrence of bacterial co-infections and severity of SARS-CoV-2 infections. Further experimental studies on the viral-bacterial interaction of SARS-CoV-2 with important facultative pathogenic commensal bacteria are needed to elucidate the occurrence of bacterial co-infections in COVID-19 patients.

\section{Influence of co-infection on the course of the disease}

Dysbiosis and immune imbalance will lead to microbial infection. Infections with more than one pathogenic agent 
may overwhelm the immune system, and the outcome is more or less unpredictable. At the time of publication, there is still limited data on the outcome and clinical presentation of multi-pathogen infection involving SARSCoV-2. Nevertheless, it has been reported that secondary co-infections in a primary viral infection can lead to complications and negative affect the course of infection [271, 272].

\section{Viral co-infections in COVID-19 patients}

There are several published reports on co-infections of hospitalized COVID-19 patients with other respiratory pathogens, with influenza $A$ and respiratory syncytial virus (RSV) being the most common co-infecting viral pathogens identified [294, 295]. Available data on the co-infections are limited mostly to case reports, and therefore, it is challenging to draw any conclusions from published data [294, 296]. Since most of these publications only report simultaneous detection of viral nucleic acid, it is not possible to assess, if certain viral respiratory infections subsequentially facilitate SARS-CoV-2 infections. Although the exact effect and outcome of patients infected with both influenza A and SARS-CoV-2 is still unclear, pre-publication data from a preprint on medRxiv suggest that co-infection may have a significant impact on morbidity and mortality, compared to influenza A or COVID-19 alone [297]. The odds of ventilator use, ICU admission and death are much greater in combined infections than in independent infections. Interestingly, the data suggested that the risk of testing positive for SARSCoV-2 was $68 \%$ lower among influenza cases, suggesting potential pathogen interaction and competition. The first wave of the COVID-19 pandemic hit the northern hemisphere in the latter part of the flu season. Therefore, the number of cases of influenza A-SARS-CoV-2 co-infections may not accurately represent the situation during the flu season.

In dengue endemic area, symptoms of COVID-19 can be mistaken for dengue fever as they are difficult to distinguish [298-300]. It has been reported that there is a potential cross-reactivity between SARS-CoV-2 and dengue viruses, which may have an effect on the accuracy of rapid serologic testing [301]. A similarity of the protein structure in an in-silico analysis between the SARS-CoV-2 spike protein and dengue envelope protein has been suggested as a potential mechanism for this cross-reactivity [302]. Most available data of dengue and SARS-CoV-2 co-infection are limited to case reports. Nonetheless, a cohort study from Argentina suggested that co-infections with both viruses does not worsen the outcome of either SARS-CoV-2 or dengue infection alone [303].

\section{Bacterial co-infections in COVID-19 patients}

In prior influenza pandemics, disease severity and increased mortality have been linked with bacterial and fungal coinfection [275, 304, 305]. Therefore, there is a major concern, whether bacterial and fungal co-infection may influence the clinical presentation of SARS-CoV-2 infections in a similar manner to influenza. In contrast to the influenza virus, in previous coronavirus epidemics, such as SARS and MERS, very little evidence of bacterial and fungal coinfections was reported [306]. From the clinical point of view, this is a very important aspect for the optimal clinical management of COVID-19 patients, whether supportive antibiotics therapy may be beneficial in treating severe COVID-19 presentations.

During the early phase of the COVID-19 pandemic, published literature reported a low rate of bacterial co-infection in hospitalized COVID-19. However, there was a high use of broad-spectrum antimicrobial substances to anticipate secondary and co-infection in the early phase of the pandemic [295, 306, 307]. High-quality evidence is lacking but is desperately needed for antibiotic stewardship and clinical management of COVID-19 patients, bearing in mind that antimicrobial resistance was and still is a major health concern regardless of the pandemic [308]. Moreover, community-acquired co- and super-infection should be clearly distinguished from hospital-acquired infections due to the different predisposing factors for the acquisition of secondary pneumonia.

Recently, Garcia-Vidal and colleagues reported that only 3\% (31/989) of COVID-19 patients admitted to a hospital in Barcelona, Spain presented with communityacquired bacterial infections. In these patients, Streptococcus pneumoniae and Staphylococcus aureus pneumonia were predominant [309]. Meanwhile, hospital-acquired infections were reported in 4\% (43/989) of the patients, with well over half of these infections occurring in the critical care setting. As expected, Pseudomonas aeruginosa, Escherichia coli, Klebsiella spp and S. aureus were among the most common pathogen identified in patients with hospital-associated pneumonia (incl. ventilatorassociated pneumonia) [309]. Similar observations have been reported by Hughes and colleagues, who reported a similarly low $(6 \% ; 51 / 836)$ occurrence of bacterial coinfections in patients admitted to a UK hospital [310]. In contrast, another study by Contour and colleagues reported a higher rate $(28 \% ; 26 / 92)$ of bacterial co-infection in COVID-19 patients admitted to the ICU of a French hospital, again with $S$. aureus, Haemophilus influenzae, S. pneumoniae, Enterobacterales and $P$. aeruginosa as the primary pathogens [311]. In this study, the patients presented with severe SARS-CoV-2 pneumoniae and, therefore, no direct comparison could be made with the aforementioned 
studies of Garcia-Visal et al. and Hughes et al. [309, 310]. In all these studies, the spectrum of the bacterial pathogen detected was similar. Commensal bacteria with pathogenic potential, such as $S$. aureus, S. pneumoniae and $H$. influenzae were commonly detected in COVID-19 patients, similar to the bacterial spectrum found in influenza patients [312]. The only difference is that the rate of bacterial coinfection in influenza is much higher than in COVID-19 patients, which may be an indication of co-incidental finding [313-315]. A meta-analysis by Klein et al. reported bacterial co-infection rates for influenza ranging from 2 to $65 \%$, with S. pneumoniae and S. aureus as the most common co-infecting species [312]. Others reports on bacterial co-infections have been published [316, 317], but were not discussed in detail in this review due to the small sample size and a case-report nature of the data presented.

The comparability of data on co-infections in COVID-19 patients relies on several essential aspects. There is no consensus definition for co-infection and secondary infection. Microbial sampling techniques and detection techniques are variable. Moreover, the distinction between contamination and true infections for several microorganisms, such as Candida spp, Enterococcus spp and coagulase-negative staphylococci, is not always clear cut. Despite some supporting evidence of the importance of bacterial co-infection in viral respiratory diseases, this aspect is still understudied in the context of COVID-19. Indeed, the diagnosis of bacterial co-infection in COVID-19 patients is a challenge. These bacteria may be part of the commensal bacteria, associated with an underlying chronic disease or acquired during hospitalization. While antibiotics are ineffective to treat SARS-CoV-2 infection, they are prescribed frequently for COVID-19. This further complicates the detection of bacterial co-infection due to the reduced sensitivity of conventional culture-based detection methods. Since there is no consensus reporting standard for studies and reports on bacterial co-infection for COVID-19, the quality of clinical data is heterogeneous. These aspects should be taken into consideration for future prospective studies.

As infection cases surge in tropical and sub-tropical regions, where tuberculosis (TB) is endemic, evidence on the potential interaction between TB and COVID-19 accumulate. In a meta-analysis of six studies from China with small study sample, TB prevalence was described to be higher among patients with severe COVID-19 compared to nonsevere cases and that the risk of TB-related mortality was 1.4 times higher in COVID-19 patients [318]. Another study based on data from the Philippines reported an increased risk (2.17 times higher) of death in TB patients co-infected with COVID-19 [319]. However, the definitive effect of COVID19 on TB progression/sequelae is still unclear. Furthermore, evidence on the causative association is still lacking. A global study initiative on TB and COVID-19 co-infections supported by the World Health Organization is currently underway [320].

Author contributions SB and MK build the concept of the review. All authors performed the literature search and wrote and critically revised the manuscript. All authors consent for publication.

Funding Open Access funding enabled and organized by Projekt DEAL. This work is supported partially by the German Ministry for Education and Research (82DZL009B1) and the German Center for Infection Research-DZIF (TTU 01.927).

\section{Declarations}

Conflict of interest The author(s) declare(s) that they have no competing interests.

Ethical approval Not applicable.

Consent to participate Not applicable.

Consent for publication Not applicable.

Open Access This article is licensed under a Creative Commons Attribution 4.0 International License, which permits use, sharing, adaptation, distribution and reproduction in any medium or format, as long as you give appropriate credit to the original author(s) and the source, provide a link to the Creative Commons licence, and indicate if changes were made. The images or other third party material in this article are included in the article's Creative Commons licence, unless indicated otherwise in a credit line to the material. If material is not included in the article's Creative Commons licence and your intended use is not permitted by statutory regulation or exceeds the permitted use, you will need to obtain permission directly from the copyright holder. To view a copy of this licence, visit http://creativecommons.org/licenses/by/4.0/.

\section{References}

1. Ksiazek TG, Erdman D, Goldsmith CS et al (2003) A novel coronavirus associated with severe acute respiratory syndrome. N Engl J Med 348:1953-1966. https://doi.org/10.1056/NEJMo a030781

2. Lu H, Stratton CW, Tang Y-W (2020) Outbreak of pneumonia of unknown etiology in Wuhan, China: the mystery and the miracle. J Med Virol 92:401-402. https://doi.org/10.1002/jmv.25678

3. Wu F, Zhao S, Yu B et al (2020) A new coronavirus associated with human respiratory disease in China. Nature 579:265-269. https://doi.org/10.1038/s41586-020-2008-3

4. Zhu N, Zhang D, Wang W et al (2020) A novel coronavirus from patients with pneumonia in China, 2019. N Engl J Med 382:727-733. https://doi.org/10.1056/NEJMoa2001017

5. Huang C, Wang Y, Li X et al (2020) Clinical features of patients infected with 2019 novel coronavirus in Wuhan, China. Lancet 395:497-506. https://doi.org/10.1016/S0140-6736(20)30183-5

6. Shi H, Han X, Jiang N et al (2020) Radiological findings from 81 patients with COVID-19 pneumonia in Wuhan, China: a descriptive study. Lancet Infect Dis 20:425-434. https://doi.org/10.1016/ S1473-3099(20)30086-4 
7. Guan W-J, Ni Z-Y, Hu Y et al (2020) Clinical characteristics of coronavirus disease 2019 in China. N Engl J Med 382:17081720. https://doi.org/10.1056/NEJMoa2002032

8. Chen N, Zhou M, Dong X et al (2020) Epidemiological and clinical characteristics of 99 cases of 2019 novel coronavirus pneumonia in Wuhan, China: a descriptive study. Lancet 395:507513. https://doi.org/10.1016/S0140-6736(20)30211-7

9. Zhou F, Yu T, Du R et al (2020) Clinical course and risk factors for mortality of adult inpatients with COVID-19 in Wuhan, China: a retrospective cohort study. Lancet 395:1054-1062. https://doi.org/10.1016/S0140-6736(20)30566-3

10. Lu X, Zhang L, Du H et al (2020) SARS-CoV-2 infection in children. N Engl J Med 382:1663-1665. https://doi.org/10.1056/ NEJMc2005073

11. Qiu H, Wu J, Hong L et al (2020) Clinical and epidemiological features of 36 children with coronavirus disease 2019 (COVID19) in Zhejiang, China: an observational cohort study. Lancet Infect Dis 20:689-696. https://doi.org/10.1016/S1473-3099(20) 30198-5

12. Abd El-Aziz TM, Stockand JD (2020) Recent progress and challenges in drug development against COVID-19 coronavirus (SARS-CoV-2) —an update on the status. Infect Genet Evol 83:104327. https://doi.org/10.1016/j.meegid.2020.104327

13. Lai C-C, Shih T-P, Ko W-C et al (2020) Severe acute respiratory syndrome coronavirus 2 (SARS-CoV-2) and coronavirus disease-2019 (COVID-19): the epidemic and the challenges. Int J Antimicrob Agents 55:105924. https://doi.org/10.1016/j.ijant imicag.2020.105924

14. Tobaiqy M, Qashqary M, Al-Dahery S et al (2020) Therapeutic management of patients with COVID-19: a systematic review. Infect Prev Pract 2:100061. https://doi.org/10.1016/j.infpip.2020. 100061

15. Jeyanathan M, Afkhami S, Smaill F et al (2020) Immunological considerations for COVID-19 vaccine strategies. Nat Rev Immunol. https://doi.org/10.1038/s41577-020-00434-6

16. Lee N, McGeer A (2020) The starting line for COVID-19 vaccine development. Lancet 395:1815-1816. https://doi.org/10.1016/ S0140-6736(20)31239-3

17. Zhu F-C, Li Y-H, Guan X-H et al (2020) Safety, tolerability, and immunogenicity of a recombinant adenovirus type-5 vectored COVID-19 vaccine: a dose-escalation, open-label, nonrandomised, first-in-human trial. Lancet 395:1845-1854. https:// doi.org/10.1016/S0140-6736(20)31208-3

18. Hotez PJ, Corry DB, Bottazzi ME (2020) COVID-19 vaccine design: the Janus face of immune enhancement. Nat Rev Immunol. https://doi.org/10.1038/s41577-020-0323-4

19. Leitner T, Kumar S (2020) Where did SARS-CoV-2 come from? Mol Biol Evol 37:2463-2464. https://doi.org/10.1093/molbev/ msaa162

20. Coronaviridae Study Group of the International Committee on Taxonomy of Viruses (2020) The species severe acute respiratory syndrome-related coronavirus: classifying 2019-nCoV and naming it SARS-CoV-2. Nat Microbiol 5:536-544. https://doi. org/10.1038/s41564-020-0695-Z

21. Kim D, Lee J-Y, Yang J-S et al (2020) The architecture of SARSCoV-2 transcriptome. Cell 181:914-921.e10. https://doi.org/10. 1016/j.cell.2020.04.011

22. Hoffmann M, Kleine-Weber H, Schroeder S et al (2020) SARSCoV-2 cell entry depends on ACE2 and TMPRSS 2 and is blocked by a clinically proven protease inhibitor. Cell 181:271280.e8. https://doi.org/10.1016/j.cell.2020.02.052

23. Bestle D, Heindl MR, Limburg $\mathrm{H}$ et al (2020) TMPRSS2 and furin are both essential for proteolytic activation of SARS-CoV-2 in human airway cells. Life Sci Alliance. https://doi.org/10. 26508/1sa.202000786
24. Kishimoto M, Uemura K, Sanaki T et al (2021) TMPRSS11D and TMPRSS13 activate the SARS-CoV-2 spike protein. Viruses 13:384

25. Prasad K, Kumar V (2021) Genomics-guided identification of potential modulators of SARS-CoV-2 entry proteases, TMPRSS2 and Cathepsins B/L. Research Square. https://doi.org/10.21203/ rs.3.rs-138273/v1

26. Ogando NS, Dalebout TJ, Zevenhoven-Dobbe JC et al (2020) SARS-coronavirus-2 replication in Vero E6 cells: replication kinetics, rapid adaptation and cytopathology. J Gen Virol 101:925-940. https://doi.org/10.1099/jgv.0.001453

27. Snijder EJ, Limpens RWAL, de Wilde AH et al (2020) A unifying structural and functional model of the coronavirus replication organelle: tracking down RNA synthesis. PLoS Biol 18:e3000715. https://doi.org/10.1371/journal.pbio.3000715

28. Wolff G, Limpens RWAL, Zevenhoven-Dobbe JC et al (2020) A molecular pore spans the double membrane of the coronavirus replication organelle. Science 369:1395-1398. https://doi. org/10.1126/science.abd3629

29. Park A, Iwasaki A (2020) Type I and type III interferonsinduction, signaling, evasion, and application to combat COVID-19. Cell Host Microbe 27:870-878. https://doi.org/ 10.1016/j.chom.2020.05.008

30. Totura AL, Whitmore A, Agnihothram S et al (2015) Tolllike receptor 3 signaling via TRIF contributes to a protective innate immune response to severe acute respiratory syndrome coronavirus infection. MBio 6:e00638. https://doi.org/10.1128/ mBio.00638-15

31. Sa Ribero M, Jouvenet N, Dreux M, Nisole S (2020) Interplay between SARS-CoV-2 and the type I interferon response. PLoS Pathog 16:e1008737. https://doi.org/10.1371/journal. ppat. 1008737

32. Choudhury A, Mukherjee S (2020) In silico studies on the comparative characterization of the interactions of SARSCoV-2 spike glycoprotein with ACE-2 receptor homologs and human TLRs. J Med Virol 92:2105-2113. https://doi.org/10. 1002/jmv.25987

33. Bhattacharya M, Sharma AR, Patra P et al (2020) Development of epitope-based peptide vaccine against novel coronavirus 2019 (SARS-COV-2): immunoinformatics approach. J Med Virol 92:618-631. https://doi.org/10.1002/jmv.25736

34. Choudhury A, Das NC, Patra R, Mukherjee S (2021) In silico analyses on the comparative sensing of SARS-CoV-2 mRNA by the intracellular TLRs of humans. J Med Virol 93:24762486. https://doi.org/10.1002/jmv.26776

35. Patra R, Chandra Das N, Mukherjee S (2021) Targeting human TLRs to combat COVID-19: a solution? J Med Virol 93:615617. https://doi.org/10.1002/jmv.26387

36. Neufeldt CJ, Cerikan B, Cortese M et al (2020) SARS-CoV-2 infection induces a pro-inflammatory cytokine response through cGAS-STING and NF-кB. bioRxiv. https://doi.org/ 10.1101/2020.07.21.212639

37. Berthelot J-M, Lioté F (2020) COVID-19 as a STING disorder with delayed over-secretion of interferon-beta. EBioMedicine 56:102801. https://doi.org/10.1016/j.ebiom.2020.102801

38. Crozat K, Beutler B (2004) TLR7: a new sensor of viral infection. Proc Natl Acad Sci U S A 101:6835-6836. https://doi. org/10.1073/pnas.0401347101

39. van der Made CI, Simons A, Schuurs-Hoeijmakers J et al (2020) Presence of genetic variants among young men with severe COVID-19. JAMA. https://doi.org/10.1001/jama.2020. 13719

40. Jensen S, Thomsen AR (2012) Sensing of RNA viruses: a review of innate immune receptors involved in recognizing RNA virus invasion. J Virol 86:2900-2910. https://doi.org/10. 1128/JVI.05738-11 
41. Streicher F, Jouvenet N (2019) Stimulation of innate immunity by host and viral RNAs. Trends Immunol 40:1134-1148. https://doi.org/10.1016/j.it.2019.10.009

42. Schoggins JW, Rice CM (2011) Interferon-stimulated genes and their antiviral effector functions. Curr Opin Virol 1:519525. https://doi.org/10.1016/j.coviro.2011.10.008

43. Stanifer ML, Pervolaraki K, Boulant S (2019) Differential regulation of type I and type III interferon signaling. Int J Mol Sci. https://doi.org/10.3390/ijms20061445

44. Sheahan TP, Sims AC, Leist SR et al (2020) Comparative therapeutic efficacy of remdesivir and combination lopinavir, ritonavir, and interferon beta against MERS-CoV. Nat Commun 11:222. https://doi.org/10.1038/s41467-019-13940-6

45. Mantlo E, Bukreyeva N, Maruyama J et al (2020) Antiviral activities of type I interferons to SARS-CoV-2 infection. Antiviral Res 179:104811. https://doi.org/10.1016/j.antiviral.2020. 104811

46. Nelemans T, Kikkert M (2019) Viral innate immune evasion and the pathogenesis of emerging RNA virus infections. Viruses. https://doi.org/10.3390/v11100961

47. Lei X, Dong X, Ma R et al (2020) Activation and evasion of type I interferon responses by SARS-CoV-2. Nat Commun 11:3810. https://doi.org/10.1038/s41467-020-17665-9

48. Li J-Y, Liao C-H, Wang Q et al (2020) The ORF6, ORF8 and nucleocapsid proteins of SARS-CoV-2 inhibit type I interferon signaling pathway. Virus Res 286:198074. https://doi.org/10. 1016/j.virusres.2020.198074

49. Bastard P, Rosen LB, Zhang Q et al (2020) Autoantibodies against type I IFNs in patients with life-threatening COVID-19. Science. https://doi.org/10.1126/science.abd4585

50. Hadjadj J, Yatim N, Barnabei L et al (2020) Impaired type I interferon activity and inflammatory responses in severe COVID-19 patients. Science 369:718-724. https://doi.org/10. 1126/science.abc6027

51. Meager A, Visvalingam K, Peterson P et al (2006) Anti-interferon autoantibodies in autoimmune polyendocrinopathy syndrome type 1. PLoS Med 3:e289. https://doi.org/10.1371/journ al.pmed.0030289

52. Panem S, Check IJ, Henriksen D, Vilcek J (1982) Antibodies to alpha-interferon in a patient with systemic lupus erythematosus. J Immunol 129:1-3

53. Rouse BT, Sehrawat S (2010) Immunity and immunopathology to viruses: what decides the outcome? Nat Rev Immunol 10:514-526. https://doi.org/10.1038/nri2802

54. Xu Z, Shi L, Wang Y et al (2020) Pathological findings of COVID-19 associated with acute respiratory distress syndrome. Lancet Respir Med 8:420-422. https://doi.org/10.1016/ S2213-2600(20)30076-X

55. da Costa VG, Moreli ML, Saivish MV (2020) The emergence of SARS, MERS and novel SARS-2 coronaviruses in the 21st century. Arch Virol 165:1517-1526. https://doi.org/10.1007/ s00705-020-04628-0

56. Rubenfeld GD, Caldwell E, Peabody E et al (2005) Incidence and outcomes of acute lung injury. N Engl J Med 353:16851693. https://doi.org/10.1056/NEJMoa050333

57. Kang S, Tanaka T, Inoue H et al (2020) IL-6 trans-signaling induces plasminogen activator inhibitor- 1 from vascular endothelial cells in cytokine release syndrome. Proc Natl Acad Sci U S A 117:22351-22356. https://doi.org/10.1073/pnas. 2010229117

58. Kox M, Waalders NJB, Kooistra EJ et al (2020) Cytokine levels in critically Ill patients with COVID-19 and other conditions. JAMA. https://doi.org/10.1001/jama.2020.17052

59. Mondal S, Quintili AL, Karamchandani K, Bose S (2020) Thromboembolic disease in COVID-19 patients: a brief narrative review. J Intensive Care 8:70. https://doi.org/10.1186/ s40560-020-00483-y

60. Björkström NK, Ljunggren H-G, Michaëlsson J (2016) Emerging insights into natural killer cells in human peripheral tissues. Nat Rev Immunol 16:310-320. https://doi.org/10.1038/ nri.2016.34

61. Raulet DH, Vance RE, McMahon CW (2001) Regulation of the natural killer cell receptor repertoire. Annu Rev Immunol 19:291-330. https://doi.org/10.1146/annurev.immunol.19.1.291

62. Paolini R, Bernardini G, Molfetta R, Santoni A (2015) NK cells and interferons. Cytokine Growth Factor Rev 26:113-120. https://doi.org/10.1016/j.cytogfr.2014.11.003

63. Kikkert M (2020) Innate immune evasion by human respiratory RNA viruses. J Innate Immun 12:4-20. https://doi.org/10.1159/ 000503030

64. Martin TR, Frevert CW (2005) Innate immunity in the lungs. Proc Am Thorac Soc 2:403-411. https://doi.org/10.1513/pats. 200508-090JS

65. Campbell KS, Hasegawa J (2013) Natural killer cell biology: an update and future directions. J Allergy Clin Immunol 132:536544. https://doi.org/10.1016/j.jaci.2013.07.006

66. Zheng M, Gao Y, Wang G et al (2020) Functional exhaustion of antiviral lymphocytes in COVID-19 patients. Cell Mol Immunol 17:533-535. https://doi.org/10.1038/s41423-020-0402-2

67. Liao M, Liu Y, Yuan J et al (2020) Single-cell landscape of bronchoalveolar immune cells in patients with COVID-19. Nat Med 26:842-844. https://doi.org/10.1038/s41591-020-0901-9

68. Demaria O, Carvelli J, Batista L et al (2020) Identification of druggable inhibitory immune checkpoints on natural killer cells in COVID-19. Cell Mol Immunol 17:995-997. https://doi.org/ 10.1038/s41423-020-0493-9

69. Wilk AJ, Rustagi A, Zhao NQ et al (2020) A single-cell atlas of the peripheral immune response in patients with severe COVID-19. Nat Med 26:1070-1076. https://doi.org/10.1038/ s41591-020-0944-y

70. Maucourant C, Filipovic I, Ponzetta A et al (2020) Natural killer cell immunotypes related to COVID-19 disease severity. Sci Immunol. https://doi.org/10.1126/sciimmunol.abd6832

71. Schulte-Schrepping J, Reusch N, Paclik D et al (2020) Severe COVID-19 is marked by a dysregulated myeloid cell compartment. Cell 182:1419-1440.e23. https://doi.org/10.1016/j.cell. 2020.08 .001

72. Shalova IN, Lim JY, Chittezhath M et al (2015) Human monocytes undergo functional re-programming during sepsis mediated by hypoxia-inducible factor- $1 \alpha$. Immunity $42: 484-498$. https:// doi.org/10.1016/j.immuni.2015.02.001

73. Giesbrecht K, Eberle M-E, Wölfle SJ et al (2017) IL-1 $\beta$ as mediator of resolution that reprograms human peripheral monocytes toward a suppressive phenotype. Front Immunol 8:899. https:// doi.org/10.3389/fimmu.2017.00899

74. Bost P, De Sanctis F, Canè S et al (2021) Deciphering the state of immune silence in fatal COVID-19 patients. Nat Commun 12:1428. https://doi.org/10.1038/s41467-021-21702-6

75. Rosendahl Huber S, van Beek J, de Jonge J et al (2014) T cell responses to viral infections-opportunities for peptide vaccination. Front Immunol 5:171. https://doi.org/10.3389/fimmu.2014. 00171

76. Pennock ND, White JT, Cross EW et al (2013) T cell responses: naive to memory and everything in between. Adv Physiol Educ 37:273-283. https://doi.org/10.1152/advan.00066.2013

77. Swadling L, Maini MK (2020) T cells in COVID-19—united in diversity. Nat Immunol 21:1307-1308. https://doi.org/10.1038/ s41590-020-0798-y

78. Le Bert N, Tan AT, Kunasegaran K et al (2020) SARS-CoV2 -specific $T$ cell immunity in cases of COVID-19 and SARS, 
and uninfected controls. Nature 584:457-462. https://doi.org/10. $1038 / \mathrm{s} 41586-020-2550-\mathrm{z}$

79. Sette A, Crotty S (2020) Pre-existing immunity to SARS-CoV-2: the knowns and unknowns. Nat Rev Immunol 20:457-458. https://doi.org/10.1038/s41577-020-0389-z

80. Zhou R, To KK-W, Wong Y-C et al (2020) Acute SARS-CoV-2 infection impairs dendritic cell and $\mathrm{T}$ cell responses. Immunity 53:864-877.e5. https://doi.org/10.1016/j.immuni.2020.07.026

81. Chen Z, John Wherry E (2020) T cell responses in patients with COVID-19. Nat Rev Immunol 20:529-536. https://doi.org/10. 1038/s41577-020-0402-6

82. Urra JM, Cabrera CM, Porras L, Ródenas I (2020) Selective CD8 cell reduction by SARS-CoV-2 is associated with a worse prognosis and systemic inflammation in COVID-19 patients. Clin Immunol 217:108486. https://doi.org/10.1016/j.clim.2020. 108486

83. Li CK, Wu H, Yan $\mathrm{H}$ et al (2008) T cell responses to whole SARS coronavirus in humans. J Immunol 181:5490-5500. https://doi. org/10.4049/jimmunol.181.8.5490

84. Sekine T, Perez-Potti A, Rivera-Ballesteros O et al (2020) Robust $\mathrm{T}$ cell immunity in convalescent individuals with asymptomatic or mild COVID-19. Cell 183:158-168.e14. https://doi.org/10. 1016/j.cell.2020.08.017

85. Grifoni A, Weiskopf D, Ramirez SI et al (2020) Targets of T cell responses to SARS-CoV-2 coronavirus in humans with COVID19 disease and unexposed individuals. Cell 181:1489-1501.e15. https://doi.org/10.1016/j.cell.2020.05.015

86. Esteve A, Permanyer I, Boertien D, Vaupel JW (2020) National age and coresidence patterns shape COVID-19 vulnerability. PNAS 117:16118-16120. https://doi.org/10.1073/pnas.20087 64117

87. Bukowska A, Spiller L, Wolke C et al (2017) Protective regulation of the ACE2/ACE gene expression by estrogen in human atrial tissue from elderly men. Exp Biol Med (Maywood) 242:1412-1423. https://doi.org/10.1177/1535370217718808

88. Sanyaolu A, Okorie C, Marinkovic A et al (2020) Comorbidity and its impact on patients with COVID-19. SN Compr Clin Med. https://doi.org/10.1007/s42399-020-00363-4

89. Gold MS, Sehayek D, Gabrielli S et al (2020) COVID-19 and comorbidities: a systematic review and meta-analysis. Postgrad Med. https://doi.org/10.1080/00325481.2020.1786964

90. Yang J, Zheng Y, Gou X et al (2020) Prevalence of comorbidities and its effects in patients infected with SARS-CoV-2: a systematic review and meta-analysis. Int J Infect Dis 94:91-95. https:// doi.org/10.1016/j.ijid.2020.03.017

91. Wang B, Li R, Lu Z, Huang Y (2020) Does comorbidity increase the risk of patients with COVID-19: evidence from meta-analysis. Aging (Albany NY) 12:6049-6057. https://doi.org/10.18632/ aging. 103000

92. Atkins JL, Masoli JAH, Delgado J et al (2020) Preexisting comorbidities predicting COVID-19 and mortality in the UK biobank community cohort. J Gerontol A Biol Sci Med Sci 75:2224-2230. https://doi.org/10.1093/gerona/glaa183

93. Emami A, Javanmardi F, Pirbonyeh N, Akbari A (2020) Prevalence of underlying diseases in hospitalized patients with COVID-19: a systematic review and meta-analysis. Arch Acad Emerg Med 8(1):e35

94. Drake TM, Docherty AB, Harrison EM et al (2020) Outcome of hospitalization for COVID-19 in patients with Interstitial lung disease: an international multicenter study. Am J Respir Crit Care Med. https://doi.org/10.1164/rccm.202007-2794OC

95. Ferrario CM, Jewell J, Chappell MC et al (2005) Effect of angiotensin-converting enzyme inhibition and angiotensin II receptor blockers on cardiac angiotensin-converting enzyme 2. Circulation 111:2605-2610. https://doi.org/10.1161/CIRCULATIO NAHA.104.510461
96. Furuhashi M, Moniwa N, Mita T et al (2015) Urinary angiotensin-converting enzyme 2 in hypertensive patients may be increased by olmesartan, an angiotensin II receptor blocker. Am J Hypertens 28:15-21. https://doi.org/10.1093/ajh/hpu086

97. Li XC, Zhang J, Zhuo JL (2017) The vasoprotective axes of the renin-angiotensin system: physiological relevance and therapeutic implications in cardiovascular, hypertensive and kidney diseases. Pharmacol Res 125:21-38. https://doi.org/10.1016/j. phrs.2017.06.005

98. Guo T, Fan Y, Chen M et al (2020) Cardiovascular implications of fatal outcomes of patients with coronavirus disease 2019 (COVID-19). JAMA Cardiol 5:811-818. https://doi.org/10.1001/ jamacardio.2020.1017

99. Meng J, Xiao G, Zhang J et al (2020) Renin-angiotensin system inhibitors improve the clinical outcomes of COVID-19 patients with hypertension. Emerg Microbe Infect 9:757-760. https://doi. org/10.1080/22221751.2020.1746200

100. Singh AK, Gupta R, Misra A (2020) Comorbidities in COVID19: outcomes in hypertensive cohort and controversies with renin angiotensin system blockers. Diabetes Metab Syndr 14:283-287. https://doi.org/10.1016/j.dsx.2020.03.016

101. Zheng Y-Y, Ma Y-T, Zhang J-Y, Xie X (2020) COVID-19 and the cardiovascular system. Nat Rev Cardiol 17:259-260. https://doi.org/10.1038/s41569-020-0360-5

102. Teuwen L-A, Geldhof V, Pasut A, Carmeliet P (2020) COVID19: the vasculature unleashed. Nat Rev Immunol 20:389-391. https://doi.org/10.1038/s41577-020-0343-0

103. Sakabe M, Yoshioka R, Fujiki A (2013) Sick sinus syndrome induced by interferon and ribavirin therapy in a patient with chronic hepatitis C. J Cardiol Cases 8:173-175. https://doi.org/ 10.1016/j.jccase.2013.08.002

104. Wang D, Hu B, Hu C et al (2020) Clinical characteristics of 138 hospitalized patients with 2019 novel coronavirus-infected pneumonia in Wuhan, China. JAMA 323:1061-1069. https:// doi.org/10.1001/jama.2020.1585

105. Wong CK, Lam CWK, Wu AKL et al (2004) Plasma inflammatory cytokines and chemokines in severe acute respiratory syndrome. Clin Exp Immunol 136:95-103. https://doi.org/10. 1111/j.1365-2249.2004.02415.x

106. Mitrani RD, Dabas N, Goldberger JJ (2020) COVID-19 cardiac injury: implications for long-term surveillance and outcomes in survivors. Heart Rhythm. https://doi.org/10.1016/j.hrthm. 2020.06.026

107. Puntmann VO, Carerj ML, Wieters I et al (2020) Outcomes of cardiovascular magnetic resonance imaging in patients recently recovered from coronavirus disease 2019 (COVID-19). JAMA Cardiol. https://doi.org/10.1001/jamacardio.2020.3557

108. Cornier M-A, Dabelea D, Hernandez TL et al (2008) The metabolic syndrome. Endocr Rev 29:777-822. https://doi.org/10. 1210/er.2008-0024

109. Costa FF, Rosário WR, Ribeiro Farias AC et al (2020) Metabolic syndrome and COVID-19: an update on the associated comorbidities and proposed therapies. Diabetes Metab Syndr 14:809-814. https://doi.org/10.1016/j.dsx.2020.06.016

110. Inzucchi SE (2013) Diagnosis of diabetes. N Engl J Med 368:193. https://doi.org/10.1056/NEJMc1212738

111. Ma RCW, Holt RIG (2020) COVID-19 and diabetes. Diabet Med 37:723-725. https://doi.org/10.1111/dme.14300

112. Singh AK, Gupta R, Ghosh A, Misra A (2020) Diabetes in COVID-19: prevalence, pathophysiology, prognosis and practical considerations. Diabetes Metab Syndr 14:303-310. https:// doi.org/10.1016/j.dsx.2020.04.004

113. Roca-Ho H, Riera M, Palau V et al (2017) Characterization of ACE and ACE2 expression within different organs of the NOD mouse. Int J Mol Sci. https://doi.org/10.3390/ijms 18030563 
114. Fernandez C, Rysä J, Almgren P et al (2018) Plasma levels of the proprotein convertase furin and incidence of diabetes and mortality. J Intern Med 284:377-387. https://doi.org/10.1111/ joim. 12783

115. Geerlings SE, Hoepelman AIM (1999) Immune dysfunction in patients with diabetes mellitus (DM). FEMS Immunol Med Microbiol 26:259-265. https://doi.org/10.1111/j.1574-695X. 1999.tb01397.x

116. Knapp S (2013) Diabetes and infection: is there a link?-a mini-review. Gerontology 59:99-104. https://doi.org/10.1159/ 000345107

117. Kassir R (2020) Risk of COVID-19 for patients with obesity. Obes Rev. https://doi.org/10.1111/obr.13034

118. X J, C Y, S L et al (2020) Two things about COVID-19 might need attention. https://doi.org/10.20944/preprints202002.0315. v1

119. Mancuso P (2016) The role of adipokines in chronic inflammation. Immunotargets Ther 5:47-56. https://doi.org/10.2147/ ITT.S73223

120. Ryan PM, Caplice NM (2020) Is adipose tissue a reservoir for viral spread, immune activation, and cytokine amplification in coronavirus disease 2019? Obesity 28:1191-1194. https://doi. org/10.1002/oby.22843

121. Al-Goblan AS, Al-Alfi MA, Khan MZ (2014) Mechanism linking diabetes mellitus and obesity. Diabetes Metab Syndr Obes 7:587-591. https://doi.org/10.2147/DMSO.S67400

122. Lockhart SM, O'Rahilly S (2020) When two pandemics meet: why is obesity associated with increased COVID-19 mortality? Med (N Y). https://doi.org/10.1016/j.medj.2020.06.005

123. Cinti S, Mitchell G, Barbatelli G et al (2005) Adipocyte death defines macrophage localization and function in adipose tissue of obese mice and humans. J Lipid Res 46:2347-2355. https:// doi.org/10.1194/jlr.M500294-JLR200

124. Vilahur G, Ben-Aicha S, Badimon L (2017) New insights into the role of adipose tissue in thrombosis. Cardiovasc Res 113:10461054. https://doi.org/10.1093/cvr/cvx086

125. Ahmed S, Zimba O, Gasparyan AY (2020) Thrombosis in coronavirus disease 2019 (COVID-19) through the prism of Virchow's triad. Clin Rheumatol 39:2529-2543. https://doi.org/10. 1007/s10067-020-05275-1

126. Scherer PE (2019) The many secret lives of adipocytes: implications for diabetes. Diabetologia 62:223-232. https://doi.org/10. 1007/s00125-018-4777-x

127. Summer R, Fiack CA, Ikeda Y et al (2009) Adiponectin deficiency: a model of pulmonary hypertension associated with pulmonary vascular disease. Am J Physiol Lung Cell Mol Physiol 297:L432-438. https://doi.org/10.1152/ajplung.90599.2008

128. Duncan BB, Schmidt MI, Pankow JS et al (2004) Adiponectin and the development of type 2 diabetes: the atherosclerosis risk in communities study. Diabetes 53:2473-2478. https://doi.org/ 10.2337/diabetes.53.9.2473

129. Adamczak M, Rzepka E, Chudek J, Wiecek A (2005) Ageing and plasma adiponectin concentration in apparently healthy males and females. Clin Endocrinol (Oxf) 62:114-118. https://doi.org/ 10.1111/j.1365-2265.2004.02182.x

130. Cnop M, Havel PJ, Utzschneider KM et al (2003) Relationship of adiponectin to body fat distribution, insulin sensitivity and plasma lipoproteins: evidence for independent roles of age and sex. Diabetologia 46:459-469. https://doi.org/10.1007/ s00125-003-1074-Z

131. Yin Y, Wunderink RG (2018) MERS, SARS and other coronaviruses as causes of pneumonia. Respirology 23:130-137. https:// doi.org/10.1111/resp.13196
132. Leung JM, Niikura M, Yang CWT, Sin DD (2020) COVID-19 and COPD. Eur Respir J. https://doi.org/10.1183/13993003. 02108-2020

133. Alqahtani JS, Oyelade T, Aldhahir AM et al (2020) Prevalence, severity and mortality associated with COPD and smoking in patients with COVID-19: a rapid systematic review and metaanalysis. PLoS ONE 15:e0233147. https://doi.org/10.1371/journ al.pone. 0233147

134. Kim E-J, Yoon S-J, Kim Y-E et al (2019) Effects of aging and smoking duration on cigarette smoke-induced COPD severity. J Korean Med Sci 34:e90. https://doi.org/10.3346/jkms.2019.34. e90

135. Olloquequi J (2020) COVID-19 susceptibility in chronic obstructive pulmonary disease. Eur J Clin Invest 50:e13382. https://doi. org/10.1111/eci.13382

136. Singh D, Agusti A, Anzueto A et al (2019) Global strategy for the diagnosis, management, and prevention of chronic obstructive lung disease: the GOLD science committee report 2019. Eur Respir J. https://doi.org/10.1183/13993003.00164-2019

137. Guan W-J, Liang W-H, Zhao Y et al (2020) Comorbidity and its impact on 1590 patients with COVID-19 in China: a nationwide analysis. Eur Respir J. https://doi.org/10.1183/13993003. 00547-2020

138. Li X, Xu S, Yu M et al (2020) Risk factors for severity and mortality in adult COVID-19 inpatients in Wuhan. J Allergy Clin Immunol 146:110-118. https://doi.org/10.1016/j.jaci.2020.04. 006

139. Feng Y, Ling Y, Bai T et al (2020) COVID-19 with different severities: a multicenter study of clinical features. Am J Respir Crit Care Med 201:1380-1388. https://doi.org/10.1164/rccm. 202002-0445OC

140. Leung JM, Yang CX, Tam A et al (2020) ACE-2 expression in the small airway epithelia of smokers and COPD patients: implications for COVID-19. Eur Respir J. https://doi.org/10. 1183/13993003.00688-2020

141. Cai G, Bossé Y, Xiao F et al (2020) Tobacco smoking increases the lung gene expression of ACE2, the receptor of SARS-CoV-2. Am J Respir Crit Care Med 201:1557-1559. https://doi.org/10. 1164/rccm.202003-0693LE

142. Bhat TA, Panzica L, Kalathil SG, Thanavala Y (2015) Immune dysfunction in patients with chronic obstructive pulmonary disease. Ann Am Thorac Soc 12(Suppl 2):S169-175. https://doi.org/ 10.1513/AnnalsATS.201503-126AW

143. Lommatzsch M, Bratke K, Knappe T et al (2010) Acute effects of tobacco smoke on human airway dendritic cells in vivo. Eur Respir J 35:1130-1136. https://doi.org/10.1183/09031936.00090 109

144. Yamasaki K, van Eeden SF (2018) Lung macrophage phenotypes and functional responses: role in the pathogenesis of COPD. Int J Mol Sci. https://doi.org/10.3390/ijms19020582

145. García-Valero J, Olloquequi J, Montes JF et al (2019) Deficient pulmonary IFN- $\beta$ expression in COPD patients. PLoS ONE 14:e0217803. https://doi.org/10.1371/journal.pone.0217803

146. Gohy ST, Detry BR, Lecocq M et al (2014) Polymeric immunoglobulin receptor down-regulation in chronic obstructive pulmonary disease. Persistence in the cultured epithelium and role of transforming growth factor- $\beta$. Am J Respir Crit Care Med 190:509-521. https://doi.org/10.1164/rccm.201311-1971OC

147. Chiappori A, Folli C, Balbi F et al (2016) CD4(+)CD25(high) CD127(-) regulatory T-cells in COPD: smoke and drugs effect. World Allergy Organ J 9:5. https://doi.org/10.1186/ s40413-016-0095-2

148. Contoli M, Message SD, Laza-Stanca V et al (2006) Role of deficient type III interferon- $\lambda$ production in asthma exacerbations. Nat Med 12:1023-1026. https://doi.org/10.1038/nm1462 
149. Carli G, Cecchi L, Stebbing J et al (2020) Is asthma protective against COVID-19? Allergy. https://doi.org/10.1111/all.14426

150. Chhiba KD, Patel GB, Vu THT et al (2020) Prevalence and characterization of asthma in hospitalized and nonhospitalized patients with COVID-19. J Allergy Clin Immunol 146:307-314. e4. https://doi.org/10.1016/j.jaci.2020.06.010

151. Song J, Zeng M, Wang $\mathrm{H}$ et al (2021) Distinct effects of asthma and COPD comorbidity on disease expression and outcome in patients with COVID-19. Allergy. https://doi.org/10.1111/all. 14517

152. Baffi CW, Winnica DE, Holguin F (2015) Asthma and obesity: mechanisms and clinical implications. Asthma Res Pract. https:// doi.org/10.1186/s40733-015-0001-7

153. Boulet L-P, Boulay M-È (2011) Asthma-related comorbidities. Expert Rev Respir Med 5:377-393. https://doi.org/10.1586/ers. 11.34

154. Phillips N, Park I-W, Robinson JR, Jones HP (2020) The perfect storm: COVID-19 health disparities in US Blacks. J Racial Ethn Health Disparities. https://doi.org/10.1007/s40615-020-00871-y

155. Sze S, Pan D, Nevill CR et al (2020) Ethnicity and clinical outcomes in COVID-19: a systematic review and meta-analysis. EClinicalMedicine. https://doi.org/10.1016/j.eclinm.2020. 100630

156. Ajilore O, Thames AD (2020) The fire this time: the stress of racism, inflammation and COVID-19. Brain Behav Immun. https:// doi.org/10.1016/j.bbi.2020.06.003

157. Lassale C, Gaye B, Hamer M et al (2020) Ethnic disparities in hospitalisation for COVID-19 in England: the role of socioeconomic factors, mental health, and inflammatory and pro-inflammatory factors in a community-based cohort study. Brain Behav Immun 88:44-49

158. Bassett MT, Chen JT, Krieger N (2020) Variation in racial/ethnic disparities in COVID-19 mortality by age in the United States: a cross-sectional study. PLoS Med. https://doi.org/10.1371/journ al.pmed.1003402

159. Gelemanović A. Host genetics in susceptibility to respiratory infectious diseases. Respiratory tract infections-genetics medicina doktorska disertacija. Available from: http://library. foi.hr/lib/knjiga.php?B =1\&sqlx =X02169\&H=

160. Group SC-19 G (2020) Genomewide association study of severe Covid-19 with respiratory failure. N Engl J Med 383:1522-1534

161. Pairo-Castineira E, Clohisey S, Klaric L et al (2021) Genetic mechanisms of critical illness in Covid-19. Nature 591:92-98

162. Shelton JF, Shastri AJ, Ye C et al (2020) Trans-ethnic analysis reveals genetic and non-genetic associations with COVID-19 susceptibility and severity. Nat Gene. https://doi.org/10.1038/ s41588-021-00854-7

163. Vuille-dit-Bille RN, Camargo SM, Emmenegger L et al (2015) Human intestine luminal ACE2 and amino acid transporter expression increased by ACE-inhibitors. Amino Acids 47:693-705

164. Yao Y, Ye F, Li K et al (2021) Genome and epigenome editing identify CCR9 and SLC6A20 as target genes at the 3p21. 31 locus associated with severe COVID-19. Signal Transduct Target Ther 6:1-3

165. Katz DH, Tahir UA, Ngo D et al (2020) Proteomic profiling in biracial cohorts implicates DC-SIGN as a mediator of genetic risk in COVID-19. medRxiv. https://doi.org/10.1101/2020.06. 09.20125690

166. Parkinson N, Rodgers N, Fourman MH et al (2020) Dynamic data-driven meta-analysis for prioritisation of host genes implicated in COVID-19. Sci Rep 10:1-12

167. Goel R, Bloch EM, Pirenne F et al (2021) ABO blood group and COVID-19: a review on behalf of the ISBT COVID-19 working group. Vox San. https://doi.org/10.1111/vox.13076
168. Liu N, Zhang T, Ma L et al (2020) The impact of ABO blood group on COVID-19 infection risk and mortality: a systematic review and meta-analysis. Blood Rev. https://doi.org/10.1016/j. blre.2020.100785

169. Gérard C, Maggipinto G, Minon J-M (2020) COVID-19 and ABO blood group: another viewpoint. Br J Haematol 190:e93-e94

170. Dai X (2020) ABO blood group predisposes to COVID-19 severity and cardiovascular diseases. Eur J Prev Cardiol 27:1436-1437

171. Wang L, Balmat TJ, Antonia AL et al (2020) An atlas connecting shared genetic architecture of human diseases and molecular phenotypes provides insight into COVID-19 susceptibility. medRxiv. https://doi.org/10.1101/2020.12.20.20248572

172. Amraei R, Napoleon M, Yin W et al (2020) CD209L/L-SIGN and CD209/DC-SIGN act as receptors for SARS-CoV-2 and are differentially expressed in lung and kidney epithelial and endothelial cells. bioRxiv. https://doi.org/10.1101/2020.06.22. 165803

173. Velavan TP, Meyer CG (2020) The COVID-19 epidemic. Tropical Med Int Health 25:278

174. Pinto BG, Oliveira AE, Singh Y et al (2020) ACE2 expression is increased in the lungs of patients with comorbidities associated with severe COVID-19. J Infect Dis 222:556-563

175. Vieira C, Nery L, Martins L et al (2020) Downregulation of membrane-bound angiotensin converting enzyme 2 (ACE2) receptor has a pivotal role in COVID-19 immunopathology. Curr Drug Targets. https://doi.org/10.2174/138945012166620 1020154033

176. Velavan TP, Meyer CG, Esen M et al (2021) COVID-19 and syndemic challenges in battling the big three HIV TB and malaria. Int J Infect Dis. https://doi.org/10.1016/j.ijid.2021. 03.071

177. Gómez J, Albaiceta GM, García-Clemente M et al (2020) Angiotensin-converting enzymes (ACE, ACE2) gene variants and COVID-19 outcome. Gene. https://doi.org/10.1016/j.gene.2020. 145102

178. Itoyama S, Keicho N, Quy T et al (2004) ACE1 polymorphism and progression of SARS. Biochem Biophys Res Commun 323:1124-1129

179. Yildirim Z, Sahin OS, Yazar S, Cetintas VB (2021) Genetic and epigenetic factors associated with increased severity of Covid-19. Cell Biol Int. https://doi.org/10.1002/cbin.11572

180. Latini A, Agolini E, Novelli A et al (2020) COVID-19 and genetic variants of protein involved in the SARS-CoV-2 entry into the host cells. Genes 11:1010

181. Nguyen A, David JK, Maden SK et al (2020) Human leukocyte antigen susceptibility map for severe acute respiratory syndrome coronavirus 2. J Virol. https://doi.org/10.1128/JVI.00510-20

182. Wang F, Huang S, Gao R et al (2020) Initial whole-genome sequencing and analysis of the host genetic contribution to COVID-19 severity and susceptibility. Cell Discov 6:1-16

183. Vietzen H, Zoufaly A, Traugott M et al (2021) Deletion of the NKG2C receptor encoding KLRC2 gene and HLA-E variants are risk factors for severe COVID-19. Genet Med. https://doi.org/10. 1038/s41436-020-01077-7

184. Chu H, Chan JF-W, Wang Y et al (2020) Comparative replication and immune activation profiles of SARS-CoV-2 and SARS-CoV in human lungs: an ex vivo study with implications for the pathogenesis of COVID-19. Clin Infect Dis 71:1400-1409

185. Zhang Q, Bastard $P$, Liu $Z$ et al (2020) Inborn errors of type I IFN immunity in patients with life-threatening COVID-19. Science. https://doi.org/10.1126/science.abd4570

186. Pevsner-Fischer M, Blacher E, Tatirovsky E et al (2017) The gut microbiome and hypertension. Curr Opin Nephrol Hypertens 26:1-8. https://doi.org/10.1097/MNH.0000000000000293

187. Singer-Englar T, Barlow G, Mathur R (2019) Obesity, diabetes, and the gut microbiome: an updated review. Expert Rev 
Gastroenterol Hepatol 13:3-15. https://doi.org/10.1080/17474 124.2019.1543023

188. Mammen MJ, Sethi S (2016) COPD and the microbiome. Respirology 21:590-599. https://doi.org/10.1111/resp.12732

189. Loverdos K, Bellos G, Kokolatou L et al (2019) Lung microbiome in asthma: current perspectives. J Clin Med 8:1967. https:// doi.org/10.3390/jcm8111967

190. Aleman FDD, Valenzano DR (2019) Microbiome evolution during host aging. PLoS Pathog 15:e1007727. https://doi.org/10. 1371/journal.ppat.1007727

191. Molyneaux PL, Cox MJ, Wells AU et al (2017) Changes in the respiratory microbiome during acute exacerbations of idiopathic pulmonary fibrosis. Respir Res 18:29. https://doi.org/10.1186/ s12931-017-0511-3

192. Marchesi JR, Ravel J (2015) The vocabulary of microbiome research: a proposal. Microbiome 3:31. https://doi.org/10.1186/ s40168-015-0094-5

193. Yuki K, Fujiogi M, Koutsogiannaki S (2020) COVID-19 pathophysiology: a review. Clin Immunol 215:108427. https://doi.org/ 10.1016/j.clim.2020.108427

194. Pickard JM, Zeng MY, Caruso R, Núñez G (2017) Gut microbiota: role in pathogen colonization, immune responses, and inflammatory disease. Immunol Rev 279:70-89. https://doi.org/ 10.1111/imr.12567

195. Nicholson JK, Holmes E, Kinross J et al (2012) Host-gut microbiota metabolic interactions. Science 336:1262-1267. https://doi.org/10.1126/science. 1223813

196. Dickson RP, Erb-Downward JR, Martinez FJ, Huffnagle GB (2016) The microbiome and the respiratory tract. Annu Rev Physiol 78:481-504. https://doi.org/10.1146/annurev-physi ol-021115-105238

197. Morris A, Beck JM, Schloss PD et al (2013) Comparison of the respiratory microbiome in healthy nonsmokers and smokers. Am J Respir Crit Care Med 187:1067-1075. https://doi.org/10. 1164/rccm.201210-19130C

198. Dickson RP, Erb-Downward JR, Freeman CM et al (2015) Spatial variation in the healthy human lung microbiome and the adapted island model of lung biogeography. Ann Am Thorac Soc 12:821-830. https://doi.org/10.1513/AnnalsATS. 201501-029OC

199. Charlson ES, Bittinger K, Haas AR et al (2011) Topographical continuity of bacterial populations in the healthy human respiratory tract. Am J Respir Crit Care Med 184:957-963. https://doi. org/10.1164/rccm.201104-0655OC

200. Invernizzi R, Lloyd CM, Molyneaux PL (2020) Respiratory microbiome and epithelial interactions shape immunity in the lungs. Immunology 160:171-182. https://doi.org/10.1111/imm. 13195

201. Ramírez-Labrada AG, Isla D, Artal A et al (2020) The influence of lung microbiota on lung carcinogenesis, immunity, and immunotherapy. Trends Cancer 6:86-97. https://doi.org/10.1016/j.trecan.2019.12.007

202. Nanno M, Shiohara T, Yamamoto H et al (2007) Gammadelta T cells: firefighters or fire boosters in the front lines of inflammatory responses. Immunol Rev 215:103-113. https://doi.org/10. 1111/j.1600-065X.2006.00474.x

203. Cheng M, Hu S (2017) Lung-resident $\gamma \delta \mathrm{T}$ cells and their roles in lung diseases. Immunology 151:375-384. https://doi.org/10. 1111/imm.12764

204. Gollwitzer ES, Saglani S, Trompette A et al (2014) Lung microbiota promotes tolerance to allergens in neonates via PD-L1. Nat Med 20:642-647. https://doi.org/10.1038/nm.3568

205. Pérez-Losada M, Castro-Nallar E, Bendall ML et al (2015) Dual transcriptomic profiling of host and microbiota during health and disease in pediatric asthma. PLoS ONE 10:e0131819. https://doi. org/10.1371/journal.pone.0131819
206. Dickson RP, Martinez FJ, Huffnagle GB (2014) The role of the microbiome in exacerbations of chronic lung diseases. Lancet 384:691-702. https://doi.org/10.1016/S0140-6736(14)61136-3

207. Dickson RP, Erb-Downward JR, Huffnagle GB (2013) The role of the bacterial microbiome in lung disease. Expert Rev Respir Med 7:245-257. https://doi.org/10.1586/ers.13.24

208. Molyneaux PL, Cox MJ, Willis-Owen SAG et al (2014) The role of bacteria in the pathogenesis and progression of idiopathic pulmonary fibrosis. Am J Respir Crit Care Med 190:906-913. https://doi.org/10.1164/rccm.201403-0541OC

209. Hanada S, Pirzadeh M, Carver KY, Deng JC (2018) Respiratory viral infection-induced microbiome alterations and secondary bacterial pneumonia. Front Immunol. https://doi.org/10.3389/ fimmu.2018.02640

210. Langevin S, Pichon M, Smith E et al (2017) Early nasopharyngeal microbial signature associated with severe influenza in children: a retrospective pilot study. J Gen Virol 98:2425-2437. https://doi.org/10.1099/jgv.0.000920

211. Lu H-F, Li A, Zhang T et al (2017) Disordered oropharyngeal microbial communities in H7N9 patients with or without secondary bacterial lung infection. Emerg Microbes Infect 6:e112. https://doi.org/10.1038/emi.2017.101

212. Edouard S, Million M, Bachar D et al (2018) The nasopharyngeal microbiota in patients with viral respiratory tract infections is enriched in bacterial pathogens. Eur J Clin Microbiol Infect Dis 37:1725-1733. https://doi.org/10.1007/s10096-018-3305-8

213. Yi H, Yong D, Lee K et al (2014) Profiling bacterial community in upper respiratory tracts. BMC Infect Dis 14:583. https://doi. org/10.1186/s12879-014-0583-3

214. Chaban B, Albert A, Links MG et al (2013) Characterization of the upper respiratory tract microbiomes of patients with pandemic H1N1 influenza. PLoS ONE 8:e69559. https://doi.org/10. 1371/journal.pone.0069559

215. Greninger AL, Chen EC, Sittler T et al (2010) A metagenomic analysis of pandemic influenza A (2009 H1N1) infection in patients from North America. PLoS ONE 5:e13381. https://doi. org/10.1371/journal.pone.0013381

216. Leung RK-K, Zhou J-W, Guan W et al (2013) Modulation of potential respiratory pathogens by $\mathrm{pH} 1 \mathrm{~N} 1$ viral infection. Clin Microbiol Infect 19:930-935. https://doi.org/10.1111/1469-0691. 12054

217. Bogaert D, Keijser B, Huse S et al (2011) Variability and diversity of nasopharyngeal microbiota in children: a metagenomic analysis. PLoS ONE 6:e17035. https://doi.org/10.1371/journal. pone. 0017035

218. Molyneaux PL, Mallia P, Cox MJ et al (2013) Outgrowth of the bacterial airway microbiome after rhinovirus exacerbation of chronic obstructive pulmonary disease. Am J Respir Crit Care Med 188:1224-1231. https://doi.org/10.1164/rccm. 201302-0341OC

219. Hofstra JJ, Matamoros S, van de Pol MA et al (2015) Changes in microbiota during experimental human rhinovirus infection. BMC Infect Dis 15:336. https://doi.org/10.1186/ s12879-015-1081-y

220. Gu L, Deng H, Ren Z et al (2019) Dynamic changes in the microbiome and mucosal immune microenvironment of the lower respiratory tract by influenza virus infection. Front Microbiol. https://doi.org/10.3389/fmicb.2019.02491

221. Shen Z, Xiao Y, Kang L et al (2020) Genomic diversity of severe acute respiratory syndrome-coronavirus 2 in Patients with coronavirus disease 2019. Clin Infect Dis 71:713-720. https://doi.org/ 10.1093/cid/ciaa203

222. Fan J, Li X, Gao Y et al (2020) The lung tissue microbiota features of 20 deceased patients with COVID-19. J Infect 81:e64e67. https://doi.org/10.1016/j.jinf.2020.06.047 
223. Zhang H, Ai J-W, Yang W et al (2020) Metatranscriptomic characterization of COVID-19 identified a host transcriptional classifier associated with immune signaling. Clin Infect Dis. https:// doi.org/10.1093/cid/ciaa663

224. Gu J, Han B, Wang J (2020) COVID-19: gastrointestinal manifestations and potential fecal-oral transmission. Gastroenterology 158:1518-1519. https://doi.org/10.1053/j.gastro.2020.02.054

225. Cholankeril G, Podboy A, Aivaliotis VI et al (2020) High prevalence of concurrent gastrointestinal manifestations in patients with severe acute respiratory syndrome coronavirus 2: early experience from California. Gastroenterology 159:775-777. https://doi.org/10.1053/j.gastro.2020.04.008

226. Imai Y, Kuba K, Rao S et al (2005) Angiotensin-converting enzyme 2 protects from severe acute lung failure. Nature 436:112-116. https://doi.org/10.1038/nature03712

227. Qi F, Qian S, Zhang S, Zhang Z (2020) Single cell RNA sequencing of 13 human tissues identify cell types and receptors of human coronaviruses. Biochem Biophys Res Commun 526:135-140. https://doi.org/10.1016/j.bbrc.2020.03.044

228. Wang W, Xu Y, Gao R et al (2020) Detection of SARS-CoV-2 in different types of clinical specimens. JAMA 323:1843-1844. https://doi.org/10.1001/jama.2020.3786

229. Xiao F, Tang M, Zheng X et al (2020) Evidence for gastrointestinal infection of SARS-CoV-2. Gastroenterology 158:1831-1833. e3. https://doi.org/10.1053/j.gastro.2020.02.055

230. Lamers MM, Beumer J, van der Vaart J et al (2020) SARS-CoV-2 productively infects human gut enterocytes. Science 369:50-54. https://doi.org/10.1126/science.abc1669

231. Guo M, Tao W, Flavell RA, Zhu S (2021) Potential intestinal infection and faecal-oral transmission of SARS-CoV-2. Nat Rev Gastroenterol Hepatol 18:269-283. https://doi.org/10.1038/ s41575-021-00416-6

232. Pan L, Mu M, Yang P et al (2020) Clinical characteristics of COVID-19 patients with digestive symptoms in Hubei, China: a descriptive, cross-sectional, multicenter study. Am J Gastroenterol. https://doi.org/10.14309/ajg.0000000000000620

233. Vandeputte D, Falony G, Vieira-Silva S et al (2016) Stool consistency is strongly associated with gut microbiota richness and composition, enterotypes and bacterial growth rates. Gut 65:5762. https://doi.org/10.1136/gutjnl-2015-309618

234. Vissers M, de Groot R, Ferwerda G (2014) Severe viral respiratory infections: are bugs bugging? Mucosal Immunol 7:227-238. https://doi.org/10.1038/mi.2013.93

235. Fonseca W, Lukacs NW, Ptaschinski C (2018) Factors affecting the immunity to respiratory syncytial virus: from epigenetics to microbiome. Front Immunol. https://doi.org/10.3389/fimmu. 2018.00226

236. Parada Venegas D, De la Fuente MK, Landskron G et al (2019) Short chain fatty acids (SCFAs)-mediated gut epithelial and immune regulation and its relevance for inflammatory bowel diseases. Front Immunol. https://doi.org/10.3389/fimmu.2019. 00277

237. Smith PM, Howitt MR, Panikov N et al (2013) The microbial metabolites, short-chain fatty acids, regulate colonic treg cell homeostasis. Science 341:569-573. https://doi.org/10.1126/scien ce. 1241165

238. Arpaia N, Campbell C, Fan X et al (2013) Metabolites produced by commensal bacteria promote peripheral regulatory T-cell generation. Nature 504:451-455. https://doi.org/10.1038/natur e12726

239. Goverse G, Molenaar R, Macia L et al (2017) Diet-derived short chain fatty acids stimulate intestinal epithelial cells to induce mucosal tolerogenic dendritic cells. J Immunol 198:2172-2181. https://doi.org/10.4049/jimmunol.1600165
240. Haase S, Haghikia A, Wilck N et al (2018) Impacts of microbiome metabolites on immune regulation and autoimmunity. Immunology 154:230-238. https://doi.org/10.1111/imm.12933

241. Mariño E, Richards JL, McLeod KH et al (2017) Gut microbial metabolites limit the frequency of autoimmune T cells and protect against type 1 diabetes. Nat Immunol 18:552-562. https:// doi.org/10.1038/ni.3713

242. Zhao Y, Chen F, Wu W et al (2018) GPR43 mediates microbiota metabolite SCFA regulation of antimicrobial peptide expression in intestinal epithelial cells via activation of mTOR and STAT3. Mucosal Immunol 11:752-762. https://doi.org/10.1038/mi.2017. 118

243. Kalina U, Koyama N, Hosoda T et al (2002) Enhanced production of IL-18 in butyrate-treated intestinal epithelium by stimulation of the proximal promoter region. Eur J Immunol 32:26352643. https://doi.org/10.1002/1521-4141(200209)32:9\%3c263 5::AID-IMMU2635\%3e3.0.CO;2-N

244. Schauber J, Svanholm C, Termén S et al (2003) Expression of the cathelicidin LL-37 is modulated by short chain fatty acids in colonocytes: relevance of signalling pathways. Gut 52:735-741. https://doi.org/10.1136/gut.52.5.735

245. Tao Z, Fen Z et al (2020) Alterations in gut microbiota of patients with COVID-19 during time of hospitalization. Gastroenterology. https://doi.org/10.1053/j.gastro.2020.05.048

246. Gu S, Chen Y, Wu Z et al (2020) Alterations of the gut microbiota in patients with COVID-19 or H1N1 influenza. Clin Infect Dis. https://doi.org/10.1093/cid/ciaa709

247. Zuo T, Liu Q, Zhang F et al (2020) Depicting SARS-CoV-2 faecal viral activity in association with gut microbiota composition in patients with COVID-19. Gut. https://doi.org/10.1136/ gutjnl-2020-322294

248. Gou W, Fu Y, Yue L et al (2020) Gut microbiota may underlie the predisposition of healthy individuals to COVID-19. medRxiv. https://doi.org/10.1101/2020.04.22.20076091

249. Hashimoto T, Perlot T, Rehman A et al (2012) ACE2 links amino acid malnutrition to microbial ecology and intestinal inflammation. Nature 487:477-481. https://doi.org/10.1038/nature11228

250. Dijkman R, Jebbink MF, Deijs M et al (2012) Replicationdependent downregulation of cellular angiotensin-converting enzyme 2 protein expression by human coronavirus NL63. J Gen Virol 93:1924-1929. https://doi.org/10.1099/vir.0.043919-0

251. Magrone T, Jirillo E, Magrone M (2020) Focus on receptors for coronaviruses with special reference to angiotensin-converting enzyme 2 as a potential drug target - a perspective. Endocr Metab Immune Disord Drug Targets. https://doi.org/10.2174/ 1871530320666200427112902

252. Dang AT, Marsland BJ (2019) Microbes, metabolites, and the gut-lung axis. Mucosal Immunol 12:843-850. https://doi.org/ 10.1038/s41385-019-0160-6

253. Budden KF, Gellatly SL, Wood DLA et al (2017) Emerging pathogenic links between microbiota and the gut-lung axis. Nat Rev Microbiol 15:55-63. https://doi.org/10.1038/nrmicro.2016. 142

254. Trompette A, Gollwitzer ES, Yadava K et al (2014) Gut microbiota metabolism of dietary fiber influences allergic airway disease and hematopoiesis. Nat Med 20:159-166. https://doi.org/ 10.1038/nm.3444

255. Ipci K, Altıntoprak N, Muluk NB et al (2017) The possible mechanisms of the human microbiome in allergic diseases. Eur Arch Otorhinolaryngol 274:617-626. https://doi.org/10.1007/ s00405-016-4058-6

256. Hauptmann M, Schaible UE (2016) Linking microbiota and respiratory disease. FEBS Lett 590:3721-3738. https://doi.org/10. 1002/1873-3468.12421

257. McGhee JR, Fujihashi K (2012) Inside the mucosal immune system. PLoS Biol. https://doi.org/10.1371/journal.pbio.1001397 
258. Matsuno K, Ueta H, Shu Z et al (2010) The microstructure of secondary lymphoid organs that support immune cell trafficking. Arch Histol Cytol 73:1-21. https://doi.org/10.1679/aohc.73.1

259. Bingula R, Filaire M, Radosevic-Robin N et al (2017) Desired turbulence? Gut-lung axis, immunity, and lung cancer. J Oncol. https://doi.org/10.1155/2017/5035371

260. Marsland BJ, Trompette A, Gollwitzer ES (2015) The gut-lung axis in respiratory disease. Ann Am Thorac Soc 12(Suppl 2):S150-156. https://doi.org/10.1513/AnnalsATS. 201503-133AW

261. McAleer JP, Kolls JK (2018) Contributions of the intestinal microbiome in lung immunity. Eur J Immunol 48:39-49. https:// doi.org/10.1002/eji.201646721

262. Dickson RP, Schultz MJ, van der Poll T et al (2020) Lung microbiota predict clinical outcomes in critically Ill patients. Am J Respir Crit Care Med 201:555-563. https://doi.org/10.1164/ rccm.201907-1487OC

263. Meyer NJ, Calfee CS (2017) Novel translational approaches to the search for precision therapies for acute respiratory distress syndrome. Lancet Respir Med 5:512-523. https://doi.org/10. 1016/S2213-2600(17)30187-X

264. Zhang F (2020) Washed microbiota transplantation for patients with 2019-nCoV infection: a randomized, double-blind, placebocontrolled study. clinicaltrials.gov. Available from: https://clini caltrialsgov/ct2/show/NCT04251767

265. He XX, Wu LH, Ye ZN et al (2020) Treatment of COVID-19 patients suspected with gut microbiota dysbiosis with washed microbiota transplantation: study protocol for a randomized controlled trial. Res Sq. https://doi.org/10.21203/rs.3.rs-56663/ $\mathrm{v} 1$

266. Mak JWY, Chan FKL, Ng SC (2020) Probiotics and COVID19: one size does not fit all. Lancet Gastroenterol Hepatol 5:644-645. https://doi.org/10.1016/S2468-1253(20)30122-9

267. Cho I, Blaser MJ (2012) The human microbiome: at the interface of health and disease. Nat Rev Genet 13:260-270. https:// doi.org/10.1038/nrg3182

268. Shreiner AB, Kao JY, Young VB (2015) The gut microbiome in health and in disease. Curr Opin Gastroenterol 31:69-75. https://doi.org/10.1097/MOG.0000000000000139

269. Raplee I, Walker L, Xu L et al (2021) Emergence of nosocomial associated opportunistic pathogens in the gut microbiome after antibiotic treatment. Antimicrob Resist Infect Control 10:36. https://doi.org/10.1186/s13756-021-00903-0

270. Packey CD, Sartor RB (2009) Commensal bacteria, traditional and opportunistic pathogens, dysbiosis and bacterial killing in inflammatory bowel diseases. Curr Opin Infect Dis 22:292301. https://doi.org/10.1097/QCO.0b013e32832a8a5d

271. Mulcahy ME, McLoughlin RM (2016) Staphylococcus aureus and influenza A virus: partners in coinfection. MBio. https:// doi.org/10.1128/mBio.0ss2068-16

272. Nichol KP, Cherry JD (1967) Bacterial-viral interrelations in respiratory infections of children. N Engl J Med 277:667-672. https://doi.org/10.1056/NEJM196709282771301

273. Rowe HM, Meliopoulos VA, Iverson A et al (2019) Direct interactions with influenza promote bacterial adherence during respiratory infections. Nat Microbiol 4:1328-1336. https://doi. org/10.1038/s41564-019-0447-0

274. Avadhanula V, Rodriguez CA, Devincenzo JP et al (2006) Respiratory viruses augment the adhesion of bacterial pathogens to respiratory epithelium in a viral species- and cell typedependent manner. J Virol 80:1629-1636. https://doi.org/10. 1128/JVI.80.4.1629-1636.2006

275. Rynda-Apple A, Robinson KM, Alcorn JF (2015) Influenza and bacterial superinfection: illuminating the immunologic mechanisms of disease. Infect Immun 83:3764-3770. https:// doi.org/10.1128/IAI.00298-15
276. Reddinger RM, Luke-Marshall NR, Hakansson AP, Campagnari AA (2016) Host physiologic changes induced by influenza A virus lead to Staphylococcus aureus biofilm dispersion and transition from asymptomatic colonization to invasive disease. MBio. https://doi.org/10.1128/mBio.01235-16

277. Short KR, Kasper J, van der Aa $S$ et al (2016) Influenza virus damages the alveolar barrier by disrupting epithelial cell tight junctions. Eur Respir J 47:954-966. https://doi.org/10.1183/ 13993003.01282-2015

278. Plotkowski MC, Puchelle E, Beck G et al (1986) Adherence of type I Streptococcus pneumoniae to tracheal epithelium of mice infected with influenza A/PR8 virus. Am Rev Respir Dis 134:1040-1044. https://doi.org/10.1164/arrd.1986.134.5.1040

279. Reed WP, Williams RC (1978) Bacterial adherence: first step in pathogenesis of certain infections. J Chronic Dis 31:67-72. https://doi.org/10.1016/0021-9681(78)90091-7

280. Sanford BA, Shelokov A, Ramsay MA (1978) Bacterial adherence to virus-infected cells: a cell culture model of bacterial superinfection. J Infect Dis 137:176-181. https://doi.org/10. 1093/infdis/137.2.176

281. Davison VE, Sanford BA (1981) Adherence of Staphylococcus aureus to influenza A virus-infected Madin-Darby canine kidney cell cultures. Infect Immun 32:118-126. https://doi.org/ 10.1128/IAI.32.1.118-126.1981

282. Sun K, Metzger DW (2014) Influenza infection suppresses NADPH oxidase-dependent phagocytic bacterial clearance and enhances susceptibility to secondary methicillin-resistant Staphylococcus aureus infection. J Immunol 192:3301-3307. https://doi.org/10.4049/jimmunol.1303049

283. Braun LE, Sutter DE, Eichelberger MC et al (2007) Co-infection of the cotton rat (Sigmodon hispidus) with Staphylococcus aureus and influenza A virus results in synergistic disease. Microb Pathog 43:208-216. https://doi.org/10.1016/j.micpath. 2007.03.005

284. Smith AM, McCullers JA (2014) Secondary bacterial infections in influenza virus infection pathogenesis. Curr Top Microbiol Immunol 385:327-356. https://doi.org/10.1007/82_2014_394

285. Tashiro M, Ciborowski P, Reinacher M et al (1987) Synergistic role of staphylococcal proteases in the induction of influenza virus pathogenicity. Virology 157:421-430. https://doi.org/10. 1016/0042-6822(87)90284-4

286. Opatowski L, Baguelin M, Eggo RM (2018) Influenza interaction with cocirculating pathogens and its impact on surveillance, pathogenesis, and epidemic profile: a key role for mathematical modelling. PLoS Pathog 14:e1006770. https://doi.org/10.1371/ journal.ppat. 1006770

287. Hotterbeekx A, Kumar-Singh S, Goossens H, Malhotra-Kumar S (2017) In vivo and In vitro Interactions between Pseudomonas aeruginosa and Staphylococcus spp. Front Cell Infect Microbiol 7:106. https://doi.org/10.3389/fcimb.2017.00106

288. Nurjadi D, Herrmann E, Hinderberger I, Zanger P (2013) Impaired $\beta$-defensin expression in human skin links DEFB1 promoter polymorphisms with persistent Staphylococcus aureus nasal carriage. J Infect Dis 207:666-674. https://doi.org/10.1093/ infdis/jis735

289. Nurjadi D, Kain M, Marcinek P et al (2016) Ratio of T-helper type 1 (Th1) to Th17 cytokines in whole blood is associated with human $\beta$-defensin 3 expression in skin and persistent Staphylococcus aureus nasal carriage. J Infect Dis 214:1744-1751. https://doi.org/10.1093/infdis/jiw440

290. Nurjadi D, Heeg K, Weber ANR, Zanger P (2018) Toll-like receptor 9 (TLR-9) promotor polymorphisms and gene expression are associated with persistent Staphylococcus aureus nasal carriage. Clin Microbiol Infect 24:1210.e7-1210.e12. https://doi. org/10.1016/j.cmi.2018.02.014 
291. Brown AF, Leech JM, Rogers TR, McLoughlin RM (2014) Staphylococcus aureus colonization: modulation of host immune response and impact on human vaccine design. Front Immunol 4:507. https://doi.org/10.3389/fimmu.2013.00507

292. Archer NK, Harro JM, Shirtliff ME (2013) Clearance of Staphylococcus aureus nasal carriage is $\mathrm{T}$ cell dependent and mediated through interleukin-17A expression and neutrophil influx. Infect Immun 81:2070-2075. https://doi.org/10.1128/IAI.00084-13

293. Mulcahy ME, Leech JM, Renauld J-C et al (2016) Interleukin-22 regulates antimicrobial peptide expression and keratinocyte differentiation to control Staphylococcus aureus colonization of the nasal mucosa. Mucosal Immunol 9:1429-1441. https://doi.org/ 10.1038/mi.2016.24

294. Singh B, Kaur P, Reid R-J et al (2020) COVID-19 and influenza co-infection: report of three cases. Cureus 12:e9852. https://doi. org/10.7759/cureus. 9852

295. Lansbury L, Lim B, Baskaran V, Lim WS (2020) Co-infections in people with COVID-19: a systematic review and meta-analysis. J Infect 81:266-275. https://doi.org/10.1016/j.jinf.2020.05.046

296. Azekawa S, Namkoong H, Mitamura K et al (2020) Co-infection with SARS-CoV-2 and influenza A virus. IDCases 20:e00775. https://doi.org/10.1016/j.idcr.2020.e00775

297. Stowe J, Tessier E, Zhao H et al (2020) Interactions between SARS-CoV-2 and Influenza and the impact of coinfection on disease severity: a test negative design. medRxiv. https://doi.org/ 10.1101/2020.09.18.20189647

298. Nunthavichitra S, Prapaso S, Luvira V et al (2020) Case report: COVID-19 presenting as acute undifferentiated febrile illness-a tropical world threat. Am J Trop Med Hyg 103:83-85. https:// doi.org/10.4269/ajtmh.20-0440

299. Bokhari SMMA, Mahmood F, Bokhari SMSA (2020) Case report: diagnosis of COVID-19 versus tropical diseases in Pakistan. Am J Trop Med Hyg 103:77-78. https://doi.org/10.4269/ ajtmh.20-0356

300. Saddique A, Rana MS, Alam MM et al (2020) Emergence of co-infection of COVID-19 and dengue: a serious public health threat. J Infect 81:e16-e18. https://doi.org/10.1016/j.jinf.2020. 08.009

301. Yan G, Lee CK, Lam LTM et al (2020) Covert COVID-19 and false-positive dengue serology in Singapore. Lancet Infect Dis 20:536. https://doi.org/10.1016/S1473-3099(20)30158-4

302. Lustig Y, Keler S, Kolodny R et al (2020) Potential antigenic cross-reactivity between SARS-CoV-2 and dengue viruses. Clin Infect Dis. https://doi.org/10.1093/cid/ciaa1207

303. Carosella LM, Pryluka D, Maranzana A et al (2021) Characteristics of patients co-infected with severe acute respiratory syndrome coronavirus 2 and dengue virus, Buenos Aires, Argentina, March-June 2020. Emerg Infect Dis 27:348-351. https://doi.org/ 10.3201/eid2702.203439

304. Morens DM, Taubenberger JK, Fauci AS (2008) Predominant role of bacterial pneumonia as a cause of death in pandemic influenza: implications for pandemic influenza preparedness. J Infect Dis 198:962-970. https://doi.org/10.1086/591708

305. Schauwvlieghe AFAD, Rijnders BJA, Philips N et al (2018) Invasive aspergillosis in patients admitted to the intensive care unit with severe influenza: a retrospective cohort study. Lancet Respir Med 6:782-792. https://doi.org/10.1016/S2213-2600(18) 30274-1

306. Rawson TM, Moore LSP, Zhu N et al (2020) Bacterial and fungal co-infection in individuals with coronavirus: a rapid review to support COVID-19 antimicrobial prescribing. Clin Infect Dis. https://doi.org/10.1093/cid/ciaa530

307. Langford BJ, So M, Raybardhan S et al (2020) Bacterial coinfection and secondary infection in patients with COVID-19: a living rapid review and meta-analysis. Clin Microbiol Infect. https://doi.org/10.1016/j.cmi.2020.07.016
308. Nieuwlaat R, Mbuagbaw L, Mertz D et al (2020) COVID-19 and antimicrobial resistance: parallel and interacting health emergencies. Clin Infect Dis. https://doi.org/10.1093/cid/ciaa773

309. Garcia-Vidal C, Sanjuan G, Moreno-García E et al (2020) Incidence of co-infections and superinfections in hospitalized patients with COVID-19: a retrospective cohort study. Clin Microbiol Infect. https://doi.org/10.1016/j.cmi.2020.07.041

310. Hughes S, Troise O, Donaldson $\mathrm{H}$ et al (2020) Bacterial and fungal coinfection among hospitalized patients with COVID19: a retrospective cohort study in a UK secondary-care setting. Clin Microbiol Infect 26:1395-1399. https://doi.org/10.1016/j. cmi.2020.06.025

311. Contou D, Claudinon A, Pajot O et al (2020) Bacterial and viral co-infections in patients with severe SARS-CoV-2 pneumonia admitted to a French ICU. Ann Intensive Care 10:119. https:// doi.org/10.1186/s13613-020-00736-X

312. Klein EY, Monteforte B, Gupta A et al (2016) The frequency of influenza and bacterial coinfection: a systematic review and meta-analysis. Influenza Other Respir Viruses 10:394-403. https://doi.org/10.1111/irv.12398

313. Rawson TM, Wilson RC, Holmes A (2020) Understanding the role of bacterial and fungal infection in COVID-19. Clin Microbiol Infect. https://doi.org/10.1016/j.cmi.2020.09.025

314. Chertow DS, Memoli MJ (2013) Bacterial coinfection in influenza: a grand rounds review. JAMA 309:275-282. https://doi. org/10.1001/jama.2012.194139

315. Bisno AL, Griffin JP, Van Epps KA et al (1971) Pneumonia and Hong Kong influenza: a prospective study of the 1968-1969 epidemic. Am J Med Sci 261:251-263. https://doi.org/10.1097/ 00000441-197105000-00004

316. Sharifipour E, Shams S, Esmkhani M et al (2020) Evaluation of bacterial co-infections of the respiratory tract in COVID-19 patients admitted to ICU. BMC Infect Dis 20:646. https://doi. org/10.1186/s12879-020-05374-z

317. Adler H, Ball R, Fisher M et al (2020) Low rate of bacterial coinfection in patients with COVID-19. Lancet Microbe 1:e62. https://doi.org/10.1016/S2666-5247(20)30036-7

318. Gao Y, Liu M, Chen Y et al (2021) Association between tuberculosis and COVID-19 severity and mortality: a rapid systematic review and meta-analysis. J Med Virol 93:194-196. https:// doi.org/10.1002/jmv.26311

319. Sy KTL, Haw NJL, Uy J (2020) Previous and active tuberculosis increases risk of death and prolongs recovery in patients with COVID-19. Infect Dis (Lond) 52:902-907. https://doi. org/10.1080/23744235.2020.1806353

320. Casco $\mathrm{N}$ et al (2021) TB and COVID-19 co-infection: rationale and aims of a global study. Int J Tuberc Lung Dis 25:78-80. https://doi.org/10.5588/ijtld.20.0786

321. Strollo R, Pozzilli P (2020) DPP4 inhibition: preventing SARSCoV-2 infection and/or progression of COVID-19? Diabetes Metab Res Rev 36:e3330. https://doi.org/10.1002/dmrr.3330

322. Maremanda KP, Sundar IK, Li D, Rahman I (2020) Agedependent assessment of genes involved in cellular senescence, telomere, and mitochondrial pathways in human lung tissue of smokers, COPD, and IPF: associations with SARS-CoV-2 COVID-19 ACE2-TMPRSS2-furin-DPP4 axis. Front Pharmacol 11:584637. https://doi.org/10.3389/fphar.2020.584637

323. Liu H-L, Yeh I-J, Phan NN et al (2020) Gene signatures of SARS-CoV/SARS-CoV-2-infected ferret lungs in short- and long-term models. Infect Genet Evol 85:104438. https://doi. org/10.1016/j.meegid.2020.104438

324. Raha AA, Chakraborty S, Henderson J et al (2020) Investigation of CD26, a potential SARS-CoV-2 receptor, as a biomarker of age and pathology. Biosci Rep. https://doi.org/10. 1042/BSR20203092 
325. Wang S, Li W, Hui H et al (2020) Cholesterol 25-hydroxylase inhibits SARS-CoV-2 and other coronaviruses by depleting membrane cholesterol. EMBO J. https://doi.org/10.15252/ embj.2020106057

326. Zang R, Case JB, Yutuc E et al (2020) Cholesterol 25-hydroxylase suppresses SARS-CoV-2 replication by blocking membrane fusion. Proc Natl Acad Sci U S A 117:32105-32113. https://doi.org/10.1073/pnas.2012197117

327. Zu S, Deng Y-Q, Zhou C et al (2020) 25-Hydroxycholesterol is a potent SARS-CoV-2 inhibitor. Cell Res 30:1043-1045. https://doi.org/10.1038/s41422-020-00398-1

328. Maiti AK (2020) The African-American population with a low allele frequency of SNP rs1990760 (T allele) in IFIH1 predicts less IFN-beta expression and potential vulnerability to COVID-19 infection. Immunogenetics 72:387-391. https:// doi.org/10.1007/s00251-020-01174-6

329. Yin X, Riva L, Pu Y et al (2021) MDA5 governs the innate immune response to SARS-CoV-2 in lung epithelial cells. Cell Rep 34:108628. https://doi.org/10.1016/j.celrep.2020.108628

330. Winstone H, Lista MJ, Reid AC et al (2021) The polybasic cleavage site in SARS-CoV-2 spike modulates viral sensitivity to type I interferon and IFITM2. J Virol. https://doi.org/10. 1128/JVI.02422-20

331. Buchrieser J, Dufloo J, Hubert M et al (2021) Syncytia formation by SARS-CoV-2-infected cells. EMBO J. https://doi.org/ 10.15252/embj.2020107405

332. Pfaender S, Mar KB, Michailidis E et al (2020) LY6E impairs coronavirus fusion and confers immune control of viral disease. Nat Microbiol 5:1330-1339. https://doi.org/10.1038/ s41564-020-0769-y

333. Zhao X, Zheng S, Chen D et al (2020) LY6E restricts entry of human coronaviruses, including currently pandemic SARSCoV-2. J Virol. https://doi.org/10.1128/JVI.00562-20
334. Nchioua R, Kmiec D, Müller JA et al (2020) SARS-CoV-2 Is restricted by zinc finger antiviral protein despite preadaptation to the low-CpG environment in humans. MBio. https://doi.org/ 10.1128/mBio.01930-20

335. Xia X (2020) Extreme genomic CpG deficiency in SARS-CoV-2 and evasion of host antiviral defense. Mol Biol Evol 37:26992705. https://doi.org/10.1093/molbev/msaa094

336. Wyler E, Mösbauer K, Franke V et al (2021) Transcriptomic profiling of SARS-CoV-2 infected human cell lines identifies HSP90 as target for COVID-19 therapy. iScience. https://doi.org/ 10.1016/j.isci.2021.102151

337. Li C, Chu H, Liu X et al (2020) Human coronavirus dependency on host heat shock protein 90 reveals an antiviral target. Emerg Microbes Infect 9:2663-2672. https://doi.org/10.1080/22221751. 2020.1850183

338. Tokarev A, Skasko M, Fitzpatrick K, Guatelli J (2009) Antiviral activity of the interferon-induced cellular protein BST-2/tetherin. AIDS Res Hum Retroviruses 25:1197-1210. https://doi.org/10. 1089/aid.2009.0253

339. Ratcliff J, Simmonds P (2021) Potential APOBEC-mediated RNA editing of the genomes of SARS-CoV-2 and other coronaviruses and its impact on their longer term evolution. Virology 556:62-72. https://doi.org/10.1016/j.virol.2020.12.018

340. Di Giorgio S, Martignano F, Torcia MG et al (2020) Evidence for host-dependent RNA editing in the transcriptome of SARSCoV-2. Sci Adv. https://doi.org/10.1126/sciadv.abb5813

Publisher's Note Springer Nature remains neutral with regard to jurisdictional claims in published maps and institutional affiliations. 